\title{
Effect of Gray-Body Interchange Factor and Radiating Temperature on the Thermal Response of the DT-18 Shipping Container
}

J. C. Anderson

M. R. Feldman 
This report has been reproduced directly from the best available copy.

Available to DOE and DOE contractors from the Otfice of Scientific and Technical Information, P.O. Box 62, Oak Ridge, TN 37831; prices avallable from (615) 576-8401, FTS 626-8401.

Avallable to the public from the National Technical Information Service, U.S. Department of Commerce, 5285 Port Royal Rd., Springtield, VA 22161.

This report was prepared as an account of work sponsored by an agency of the United States Government. Neither the United States Government nor any agency thereof, nor any of their employees, makes any warranty, express or implied, or assumes any legal liability or responsibility for the accuracy, completeness, or usefulness of any information, apparatus, product, or process disclosed, or represents that lts use would not infringe privately owned rights. Reference herein to any specific commercial product, process, or service by trade name, trademark, manufacturer, or otherwise, does not necessarily constitute or imply its endorsernent, recommendation, or favoring by the United States Government or any agency thereof. The views and opinions of authors expressed herein do not necessarily state or reflect those of the United States Government or any agency thereot. 
ORNL/ENG/TM-37

Martin Marietta Energy Systems, Inc., Engineering

Process Engineering

ORNL/ENG/TM- -37

DE92 010370

\title{
EFFECT OF GRAY-BODY INTERCHANGE FACTOR AND RADIATING TEMPERATURE ON THE THERMAL RESPONSE OF THE DT-18 SHIPPING CONTAINER
}

\author{
J. C. Anderson \\ M. R. Feldman
}

Date Published-February 1992

MARTIN MARIETT'A ENERGY SYSTEMS, INC.

Oak Ridge, Tennessee 37831

managing the

Oak Ridge Y-12 Plant

Oak Ridge National Laboratory

Oak Ridge K-25 Site

Paducah Gaseous Diffusion Plant

for the

U.S. DEPARTMENT OF ENERGY

under Contract No. DE-AC05-84OR21400

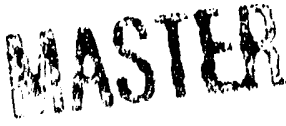


LIST OF FIGURES $\ldots \ldots \ldots \ldots \ldots \ldots \ldots$

LIST OF TABLES $\ldots \ldots \ldots \ldots \ldots \ldots \ldots \ldots \ldots \ldots \ldots \ldots \ldots$

ACKNOWLEDGMENTS $\ldots \ldots \ldots \ldots \ldots \ldots \ldots \ldots \ldots \ldots \ldots \ldots$

ABSTRACT $\ldots \ldots \ldots \ldots \ldots \ldots \ldots \ldots \ldots \ldots \ldots \ldots \ldots \ldots \ldots \ldots \ldots \ldots$

INTRODUCTION $\ldots \ldots \ldots \ldots \ldots \ldots \ldots \ldots \ldots \ldots \ldots \ldots \ldots$

CALCULATION OF THE INTERCHANGE FACTOR $\ldots \ldots \ldots \ldots \ldots$

DESCRIPTION OF CASES ANALYZED $\ldots \ldots \ldots \ldots \ldots \ldots$

DESCRIPTION OF THE HEATING MODELS $\ldots \ldots \ldots \ldots \ldots \ldots$

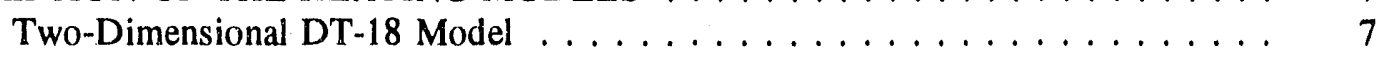

One-Dimensional DT-18 Models . . . . . . . . . . . . . . . . . 10

JUSTIFICATION FOR USING ONE-DIMENSIONAL MODELS . . . . . . . . . . 15

DISCUSSION OF RESULTS . . . . . . . . . . . . . . . . . . 21

Effect of Gray-Body Interchange Factor . . . . . . . . . . . . . 21

Effect of Radiating Temperature . . . . . . . . . . . . . . 25

RECOMMENDATIONS $\ldots \ldots \ldots \ldots \ldots \ldots \ldots \ldots \ldots \ldots \ldots \ldots \ldots \ldots$

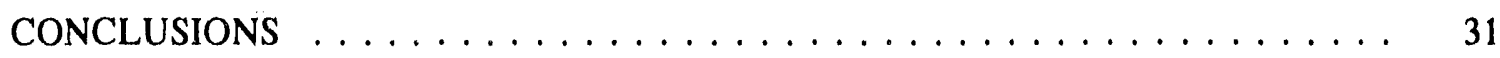

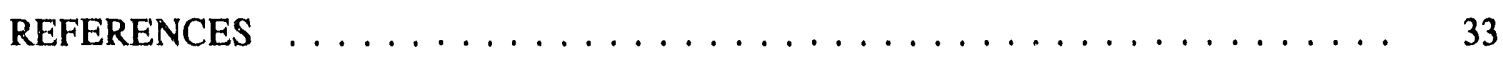

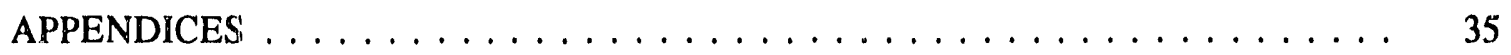

Appendix 1. Two-Dimensional DT-18 HEATING Model . . . . . . . . . . . 37

Appendix 2. One-Dimensional DT-18 HEATING Model - Side . . . . . . . 41

Appendix 3. One-Dimensional DT-18 HEATING Model - Top . . . . . . 43

Appendix 4. One-Dimensional DT-18 HEATING Model - Bottom . . . . . . 45 


\section{LIST OF FIGURES}

Page

1. DT-18 shipping container schematic $\ldots \ldots \ldots \ldots \ldots$

2. Two-dimensional DT-18 HEATING model geometry $\ldots \ldots \ldots \ldots \ldots$

3. One-dimensional DT-18 HEATING model geometries $\ldots \ldots \ldots \ldots \ldots$

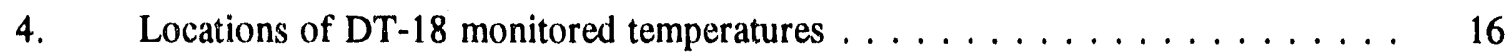

5. Effect of environment temperature on the total heat added to the DT-18 package for various gray-body interchange factors $\ldots \ldots \ldots \ldots \ldots$

6. Transient heating rate curve for the DT-18 package when exposed to an $800^{\circ} \mathrm{C}$ environment for various gray-body interchange factors . . . . . . . . .

7. Effect of gray-body interchange factor on the total heat added to the DT-18 package for various environment temperatures

8. Net heat added to the DT- 18 package when exposed to an $800^{\circ} \mathrm{C}$ environment as a function of time $\ldots \ldots \ldots \ldots \ldots \ldots$

9. Net heat added to the DT-18 package when exposed to an $800^{\circ} \mathrm{C}$ environment as a function of time 


\section{LIST OF TABLES}

Page

1. Interchange factor and radiating temperature values for cases analyzed . . . . 6

2. Material properties $\ldots \ldots \ldots \ldots \ldots \ldots \ldots$

3. Values of natural convection correlation constants $\ldots \ldots \ldots \ldots \ldots$

4. Temperatures at selected locations in 1-D and 2-D DT-18 models $\ldots \ldots \ldots 17$

5. Comparison of total heat added to DT-18 package for 1-D and 2-D

models . . . . . . . . . . . . . . . . . . . . . . . . . . . 20

6. Total heat added to DT-18 package $\ldots \ldots \ldots \ldots \ldots$

7. Time required for DT-18 package to receive heat required by 10 CFR $71 \ldots 30$ 


\section{ACKNOWLEDGMENTS}

The authors acknowledge the help and influence of several individuals who aided in the preparation of this document. W. R. Williams of Engineering Analysis was especially instrumental in providing original ideas, support, and comments as this work progressed. The members of the Energy Systems Independent Review Group committee and the Packaging Group of the Y-12 Plant Systems Safety Engineering Division and the Weapons Support Group of the Mechanical Design Division were most helpful throughout this project. E. Stumpfl of the Y-12 Packaging Program and S. D. Moses of System Safety Engineering gave continuous input as well as support during this project.

This project was performed at the request of and was funded exclusively by the $\mathrm{Y}-12$ Packaging Program. 


\begin{abstract}
Some concerns and questions have been raised regarding the values of the DT-18 package surface emissivity, the emissivity of the B-1023 furnace used for thermal testing of DOE shipping packages, and the furnace radiating temperature that should be employed during thermal tests. In order for the thermal tests performed at the Y-12 Plant in Oak Ridge, Tennessee, to comply with the regulations specified in 10 CFR 71, it must be shown that a specific arnount of heat is added to the package during the test. Therefore, a method of thermal analytical modeling was developed to calculate the quantity of heat energy input to which a DT-18 package is exposed during hypothetical accident scenario testing. Parametric studies involving the gray-body interchange factor (which embodies both the package and furnace emissivities) and the furnace radiating temperature were then performed, and the effects of these two variables on the net total heat received by a DT-18 package were determined.

The effect of the gray-body interchange factor on the total heat received by the DT-18 package was found to be minimal. Only $2 \%$ additional heat energy is imparted to the DT-18 package in a 30-min period if the interchange factor value increases from a ow value of 0.4 to a high value of 0.8 . The furnace radiating temperature, however, was fo'dnd to have a more significant effect on the total heat added to che DT-18 package. Increasing the furnace surface temperature from 800 to $850^{\circ} \mathrm{C}$ results in approximately $7 \%$ more heat entrgy being absorbed by the DT-18 package in the same time pericd.

Based on the analyses presented in this report, simple guidelines and recommendations are made in order to ensure that thermal testing in the B-1023 furnace complies with federal regulations. Data are presented which allow the determination of an appropriate furnace surface temperature $\left(800-850^{\circ} \mathrm{C}\right)$ based on the value of the gray-body interchange factor. The second alternative to ensure regulatory compliance involves allowing the DT-18 package to remain in the $800^{\circ} \mathrm{C}$ furnace for an additional amount of time (determined from presented data) beysond the required 30 -min period.
\end{abstract}




\section{INTRODUCTION}

The certification process for containers developed for shipping radioactive materials by U. S. Department of Energy (DOE) subcontractors includes thermal tests designed to simulate hypothetical fire accident scenarios. The conditions for such thermal tests, as stated in Title 10 CFR, Pt. 71.73(c)(3), ${ }^{1}$ are:

Exposure of the whole specimen for not less than 30 minutes to a heat flux not less than that of a radiation environment of $800^{\circ} \mathrm{C}\left(1475^{\circ} \mathrm{F}\right)$ with an emissivity coefficient of at least 0.9 . For purpose of calculation, the surface absorptivity must be either that value which the package may be expected to possess if exposed to a fire or 0.8 , whichever is greater. In addition, when significant, convective heat input must be included on the basis of still ambient air at $800^{\circ} \mathrm{C}$ $\left(1475^{\circ} \mathrm{F}\right)$.

Currently, the B-1023 furnace located at the Y-12 Plant in Oak Ridge, Tennessee, is being used to perform these thermal tests for packages developed there. The Energy Systems Independent Review Group (ESIRG) and DOE Field Office, Albuquerque (DOE/AL) have raised some questions regarding the actual values of the package and furnace emissivities that should be used for analysis and their effect on the total heat imparted to the package being tested.

All analyses in this report are for the DT-18 shipping container sitting in an upright position. The DT-18 package includes a 55-gal stainless steel drum (outer container) and a stainless steel inner container. The inner container has an outer diameter of $40 \mathrm{~cm}$ and a height of $57 \mathrm{~cm}$. The space between the inner and outer containers is filled with stacked rings and disks of Celotex ${ }^{\mathrm{TM}}$ fiberboard insulating material. The DT-18 package also contains two rings of plywood. The packing material inside the inner container is polyurethane foam. A sketch of the DT-18 package is shown in Fig. 1.

In order to address the concerns discussed above, a computer analysis was performed to determine the required total heat input to the DT-18 container as regulated by 10 CFR $71 .{ }^{\prime}$ Additional analyses which varied the gray-body furnace/package interchange factor and the furnace radiating temperature were performed to determine the effect of these variables on the total heat added to the DT-18 container. Also, an attempt was made to model the actual conditions thought to exist in the B-1023 furnace during thermal testing of a DT-18 shipping container and to compare the total heat input results to those obtained from the regulatory case. All thermal analyses presented in this report were performed using HEATING $7.1^{2}$ on the STC UNICOS CRAY X-MP/14 at the K-25 Site in Oak Ridge, Tennessee. 


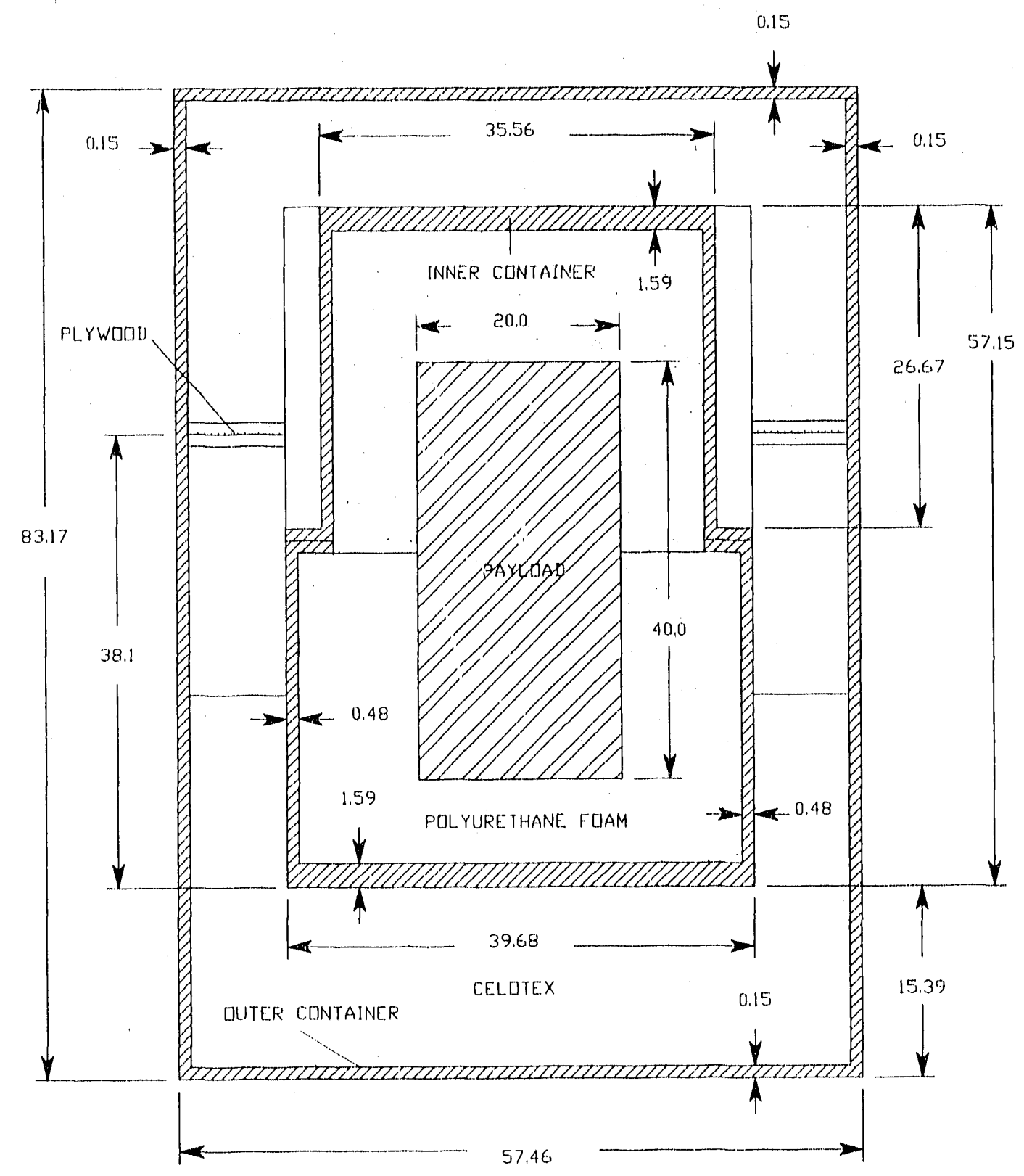

Note: All dimensions are in $\mathrm{cm}$.

Fig. 1. DT-18 shipping container schematic. 


\section{CALCULATION OF THE INTERCHANGE FACTOR}

The gray-body interchange factor between the package and the furnace interior $\left(\mathscr{T}_{\mathrm{F}}\right)$ can be calculated as: ${ }^{3}$

$$
\mathscr{T}_{\mathrm{p} F}=1 /\left[1 / \epsilon_{\mathrm{p}}+\mathrm{A}_{\mathrm{p}} / \mathrm{A}_{\mathrm{F}}\left(1 / \epsilon_{\mathrm{F}}-1\right)\right]
$$

where

$$
\begin{array}{ll}
\epsilon_{\mathrm{P}} & =\text { package emissivity, } \\
\epsilon_{\mathrm{F}} & =\text { farnace emissivity, } \\
\mathrm{A}_{\mathrm{P}} / \mathrm{A}_{\mathrm{F}} & =\text { ratio of package surface area to furnace surface area. }
\end{array}
$$

The net radiant heat flow from the furnace to the package $\left(Q_{\text {rad }}\right)$ can, therefore, be expressed as

$$
Q_{\text {rad }}=A_{p_{p}} T_{p-F} \sigma\left(T_{\mathrm{F}}^{4}-T_{\mathrm{p}}^{4}\right)
$$

where

$$
\begin{array}{ll}
\sigma & =\text { Stefan-Boltzmann constant, } \\
\mathrm{T}_{\mathrm{F}} & =\text { furnace surface temperature, } \\
\mathrm{T}_{\mathrm{p}} & =\text { package surface temperature. }
\end{array}
$$

Based on Kirchhoff's law, the total hemispherical emissivity of any surface in an enclosed blackbody cavity is equal to its total hemispherical absorptivity. A blackbody cavity is defined as a large isothermal enclosure within which one or more small bodies having a negligible influence on the radiation field are confined. ${ }^{4}$ Therefore, the package absorptivity mentioned in 10 CFR 71 and the package emissivity appearing in Eq. 1 are equivalent. 


\section{DESCRIPTION OF CASES ANALYZED}

To determine the effect of furnace emissivity, package absorptivity, and area ratio on the thermal response of the DT-18 shipping container, several cases were considered and analyzed. The interchange factors and radialing temperatures for each case are presented in Table 1. Package emissivities, furnace emissivities, and area ratios are also shown where applicable.

The first case which is considered (Case 1) is intended to represent exactly the hypothetical thermal accident condition that is called for in Title 10 CFR, Pt. 71.73(c)(3).' The properties of the model in this case include a package absorptivity of 0.8 , a furnace emissivity of 0.9 , and a package-to-furnace surface area ratio of 1.0 . The overall interchange factor for this scenario is 0.7347 . The regulations call for a radiating temperature of $800^{\circ} \mathrm{C}$.

Cases 2-10 are general cases which are intended of cover the expected ranges of interchange factors and furnace operating temperatures encouritered in practice. The value of the interchange factor is varied from 0.4 to 0.8 , and the furnce temperatures are varied from 800 to $850^{\circ} \mathrm{C}$.

Cases 11-13 are intended to approximate as closely as possible the actual conditions encountered when a DT-18 package is thermally tested in the B-1023 furnace at the Y-12 Plant. At the present time, the emissivities of the DT-18 package exteriot and the furnace walls are thought to be 0.52 and 0.61 , respectively. The actual package-to-furnace surface area ratio is approximately 0.05 , given approximate furnace dimensions of $9 \mathrm{ft}<9 \mathrm{ft} \times 9 \mathrm{ft}$. The value of the overall interchange factor for these cases is 0.5115 . The radiating surface (furnace) temperatures for Cases 11,12 , and 13 are 800,825 , and $850^{\circ} \mathrm{C}$, respectively. 
Table 1. Interchange factor and radiating temperature values for cases analyzed

\begin{tabular}{|c|c|c|c|c|c|}
\hline Case & $\epsilon_{\mathrm{p}}$ & $\epsilon_{\mathrm{F}}$ & $\mathrm{A}_{\mathrm{P}} / \mathrm{A}_{\mathrm{F}}$ & \multicolumn{1}{c|}{} & $\mathrm{T}_{\text {raded ag }}$ \\
\hline 1 & 0.8 & 0.9 & 1.0 & 0.7347 & $800^{\circ} \mathrm{C}$ \\
\hline 2 & & & & 0.4 & $800^{\circ} \mathrm{C}$ \\
\hline 3 & & & & 0.6 & $800^{\circ} \mathrm{C}$ \\
\hline 4 & & & & 0.8 & $800^{\circ} \mathrm{C}$ \\
\hline 5 & & & & 0.4 & $825^{\circ} \mathrm{C}$ \\
\hline 6 & & & & 0.6 & $825^{\circ} \mathrm{C}$ \\
\hline 7 & & & & 0.8 & $825^{\circ} \mathrm{C}$ \\
\hline 8 & & & & 0.4 & $850^{\circ} \mathrm{C}$ \\
\hline 9 & & & & 0.6 & $850^{\circ} \mathrm{C}$ \\
\hline 10 & & & & 0.8 & $850^{\circ} \mathrm{C}$ \\
\hline 11 & 0.52 & 0.61 & 0.05 & 0.5115 & $800^{\circ} \mathrm{C}$ \\
\hline 12 & 0.52 & 0.61 & 0.05 & 0.5115 & $825^{\circ} \mathrm{C}$ \\
\hline 13 & 0.52 & 0.61 & 0.05 & 0.5115 & $850^{\circ} \mathrm{C}$ \\
\hline
\end{tabular}




\section{DESCRIPTION OF THE HEATING MODELS}

\section{Two-Dimensional DT-18 Model}

A two-dimensional (2-D) $r-z$ model of the DT-18 shipping container was constructed on HEATING 7.1, a multidimensional finite difference transient heat transfer code. For more information on the HEATING 7.1 code, refer to the current HEATING user's manual. ${ }^{2}$ The HEATING 7.1 input deck for this model is presented in Appendix 1. A sketch of the DT-18 HEATING model is shown in Fig. 2. The model consists of two materials, stainless steel and Celotex $^{\mathrm{TM}}$. Both the outer and inner containers are modeled as stainless steel. Celotex ${ }^{\mathrm{TM}}$ is a fiberboard insulation used between the outer drum and inner container. Thermal properties for both 304 stainless steel and Celotex ${ }^{\mathrm{TM}}$ are presented in Table 2.

Polyurethane foam is commonly used as packing inside the inner container. However, since the thermal conductivity of polyurethane foam is relatively low, approximately $0.05-0.06 \mathrm{~W} / \mathrm{m}-\mathrm{K}$, most of the heat absorbed by the inner container will be stored rather than transferred through to the polyurethane. Therefore, as a conservative measure, the contents of the inner container, which would normally include the polyurethane insulation and the payload, were not modeled, and the inner surface of the inner container is modeled as an insulated boundary.

Some of the Celotex ${ }^{\mathrm{TM}}$ contained within the package undergoes chemical changes when exposed to the temperatures reached in thermal tests. A decomposition process takes place, and when oxygen is available a combustion process also takes place. The combination of these processes is known as pyrolysis, which is decomposition in a reducing atmosphere (i.e., no oxygen or not enough oxygen to support total combustion). The pyrolysis process will most likely have some effect on the temperature distribution through the Celotex ${ }^{\mathrm{TM}}$ with in the package, but, for simplicity, heat transfer through the Celotex ${ }^{\mathrm{TM}}$ has been modeled purely as conduction. Therefore, the Celotex ${ }^{\mathrm{TM}}$ temperatures predicted by these analyses are not considered to be accurate. When pyrolysis takes place during an actual thermal test, these processes have been shown to be exothermic. ${ }^{5}$ It would be possible for this process to increase the temperature of the outer shell of the container. As the outer shell temperature increased, the quantity of heat transferred to the package by the furnace would decrease. Thus, it is conservative not to account for the phenomena of decomposition and pyrolysis.

The boundary conditions applied to the outside of the DT-18 package are intended to simulate the actual thermal conditions imposed on the package during a standard furnace test. The sides, top, and bottom of the package therefore receive heat due to radiative exchange with the furnace interior and by natural convection with the air in the furnace. The net radiative heat flow from the furnace to the package can be determined from Eq. 2 . The natural convection heat transfer over the sides, top, and bottom of the package can be determined from

$$
Q_{\text {conv }}=h A_{\text {package }}\left(\Gamma_{A}-T_{P}\right) \text {, }
$$




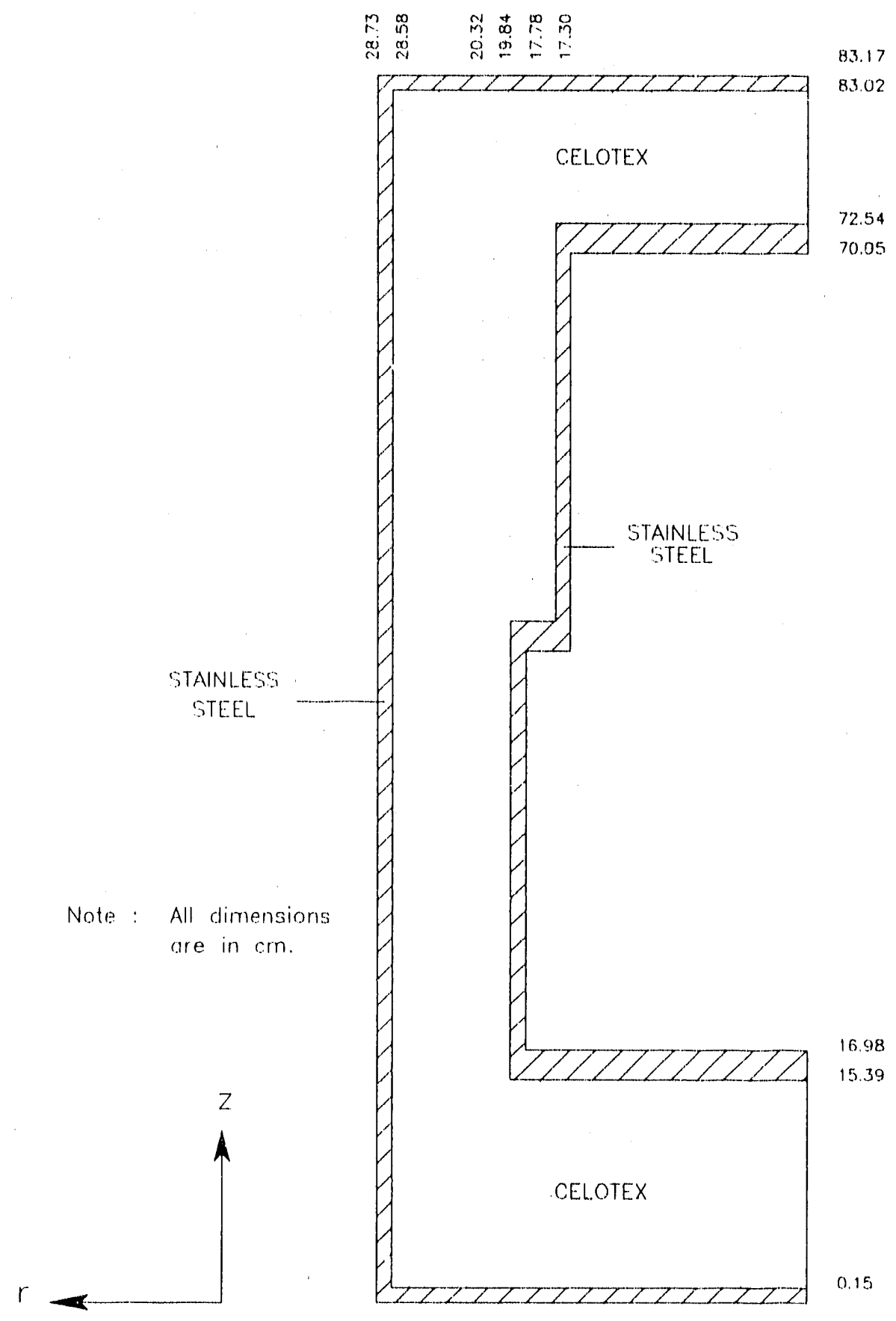

Fig. 2. Two-dimensional DT-18 HEATING model geometry. 
Table 2. Material properties

\begin{tabular}{|c|c|c|c|c|}
\hline Material & $\begin{array}{c}\text { Temperature } \\
\text { (K) }\end{array}$ & $\begin{array}{c}\text { Thermal } \\
\text { conductivity } \\
(\mathbf{W} / \mathbf{m}-\mathbf{K})\end{array}$ & $\begin{array}{l}\text { Density } \\
\left(\mathbf{k g} / \mathbf{m}^{3}\right)\end{array}$ & $\begin{array}{c}\text { Specific } \\
\text { heat } \\
(\mathbf{J} / \mathbf{k g - K})\end{array}$ \\
\hline \multirow[t]{7}{*}{ Stainless steel ${ }^{1}$} & 200 & 12.6 & \multirow[t]{7}{*}{$7900^{\circ}$} & 402 \\
\hline & 300 & 14.9 & & 477 \\
\hline & 400 & 16.6 & & 515 \\
\hline & 600 & 19.8 & & 557 \\
\hline & 800 & 22.6 & & 582 \\
\hline & 1000 & 25.4 & & 611 \\
\hline & 1200 & 28.0 & & 640 \\
\hline \multirow[t]{5}{*}{ Celotex $^{\mathrm{TM} 2}$} & 298 & 0.053 & \multirow[t]{5}{*}{$270^{\circ}$} & 1280 \\
\hline & 359 & 0.059 & & 1506 \\
\hline & 419 & 0.063 & & 1745 \\
\hline & 499 & 0.065 & & 2046 \\
\hline & 551 & 0.051 & & 2063 \\
\hline
\end{tabular}

a For modeling purposes, density was considered constant (temperature independent).

Sources: 1) Safety Analysis Report for Packaging, Oak Ridge Y-12 Plant, Model DT-23 Package with Subassembly Contents (U), Y/LF-51-IA/R1, October 26, 1990. 2) L. C. Sanchez, et al., Thermal Analysis of the 10-Gallon and the 55-Gallon DOT-6M Containers with Thermal Boundary Conditions Corresponding to 10 CFR 71 Normal Transport and Accident Conditions, Sandia Report SAND87-1896 TTC-0748, 1988. 
where

$$
h=a\left(T_{A}-T_{p}\right)^{b}
$$

and

$$
\mathrm{T}_{\mathrm{A}}=\text { furnace air temperature. }
$$

Values for the constants, $a$ and $b$, in Eq. 4 are given in Table 3 for different surface configurations. It should be noted that in the analyses the temperature of the air $\left(T_{A}\right)$ is taken as the furnace surface temperature $\left(\mathrm{T}_{\mathrm{F}}\right)$. Data consisting of control thermocouple (air) and furnace wall thermocouple temperatures support the assumption that the furnace air temperature is approximately equal to the furnace wall temperatures.' The total heat added to the package can be calculated as

$$
\mathrm{Q}_{\text {trotal }}=\mathrm{Q}_{\text {rad }}+\mathrm{Q}_{\mathrm{coxiv}} \text {. }
$$

Since initially temperature gradients are extremely sharp near the package surface, the mesh size used in the HEATING 7.1 model is small, approximately $1 / 16 \mathrm{in}$. for a depth of $1 \mathrm{in}$. into the package. The mesh size is increased to $1 / 8 \mathrm{in}$. at an intermediate region before being increased to $1 / 4$ in. near the inner container. The progressive mesh sizing, determined from preliminary one-dimensional (1-D) radial analyses on the DT-18 package, is employed in both the $r$ and $z$ directions.

Case 1 was executed using the 2-D model. Since the model consists of a total of 8731 nodes, execution time was lengthy [approximately 2.3 central processing unit (cpu) hours on the STC UNICOS CRAY]. Because of these long run times, the possibility (and resulting accuracy) of using 1-D models as opposed to 2-D models was considered.

\section{One-Dimensional DT-18 Models}

A 1-D (r) model was constructed to calculate the heat transfer to the sides of the DT-18 shipping container. One-dimensional (z) models were constructed for the top and bottom of the container. Sketches of the three 1-D models are shown in Fig. 3. The HEATING 7.1 input files for each of the three cases are presented in Appendices 2-4.

Materials and their properties are the same for these 1-D models as for the 2-D model (see Table 2 for material properties). The DT-18 side model was constructed at a height corresponding to the seal location at the inner container. The top and bottom models were constructed at locations corresponding to the centerline of the container.

The boundary conditions applied to the 1-D HEATING 7.1 models are identical to those previously described for the 2-D model. The mesh applied to the 1-D models is also similar to that described for the 2-D model. The node spacing in the side model (see Fig. 3) is $1 / 4$ in. for Region V (5 elements) and Region IV (5 elements), 1/8 in. for Region III (9 elements), and $1 / 16$ in. for Region II (16 elements) and Region I (1 element). The side model consists of a total of 37 nodes. 
Table 3. Values of natural convection correlation constants

\begin{tabular}{|c|c|c|}
\hline \hline Configuration & a & b \\
\hline \hline Vertical surface & 1.37 & 0.25 \\
\hline $\begin{array}{c}\text { Cold horizontal } \\
\text { surface facing down }\end{array}$ & 1.86 & 0.25 \\
\hline $\begin{array}{c}\text { Cold horizontal } \\
\text { surface facing up }\end{array}$ & 0.88 & 0.25 \\
\hline
\end{tabular}

Source: R. H. Perry and D. W. Green, Perry's Chemical Engineers' Handbook, 6th ed., McGraw-Hill Book Company, New York, 1984. 


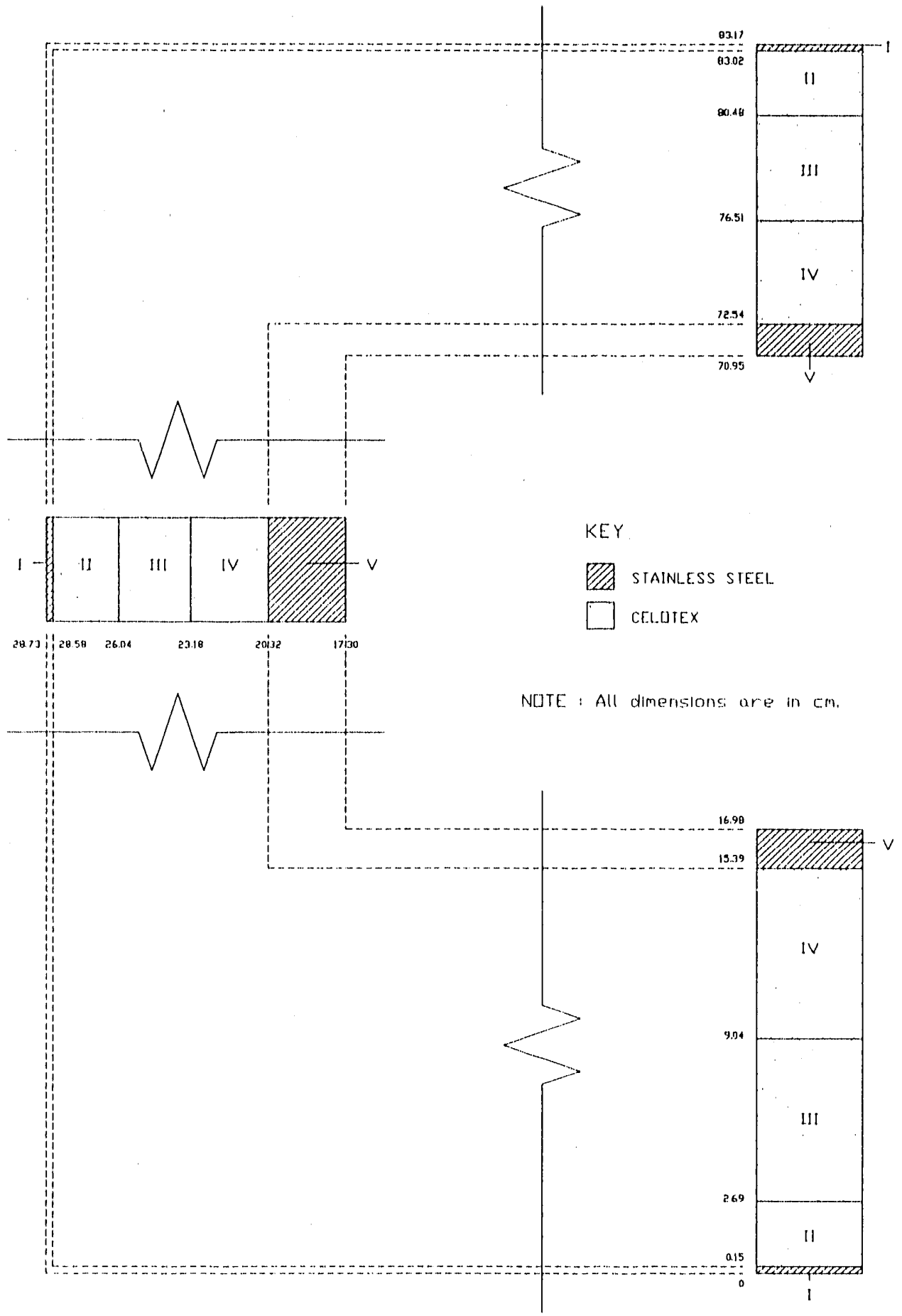

Fig. 3. One-dimensional DT-18 HEATING model geometries. 
The node spacing in the top model (see Fig. 3) is $1 / 4$ in. for Region V (3 elements) and Region IV (6 elements), 1/8 in. for Region III (13 elements), and 1/16 in. for Region II (16 elements) and Region 1 ( 1 element). The top model consists of a total of 40 nodes.

The node spacing in the bottom model (see Fig. 3) is $1 / 4$ in. for Region V (3 elements) and Region IV (10 elements), $1 / 8$ in. for Region III (20 elements), and $1 / 16$ in. for Region II (16 elements) and Region I ( 1 element). The bottom model consists of a total of 51 nodes. 


\section{JUSTIFICATION FOR USING ONE-DIMENSIONAL MODELS}

Case 1 (regulatory case) was executed using both the 1-D and 2-D HEATING models. An enormous savings in cpu time is achieved by using the 1-D model. The 2-D model takes approximately $2.3 \mathrm{cpu}$ hours on the STC UNICOS CRAY. The 1-D models (side, top, and bottom) consumed about 2 min total cpu time on the CRAY. Although this savings in cpu time is extremely significant, the accuracy of the 1-D models must be established and verified before they can be used as substitutes for the 2-D models.

Temperatures were monitored at 18 locations (each location was a region interface) in both the 1-D and 2-D models. The positions of the 18 monitored locations are shown in Fig. 4. Nodes 3,9 , and 15 are each located $2.54 \mathrm{~cm}\left(1 \mathrm{in}\right.$.) into the Celotex ${ }^{\mathrm{TM}}$ insulating material. Table 4 contains the temperatures calculated by HEATING for both the 1-D and 2-D models at each location. It is evident from the data that practically no accuracy in temperatures is forfeited by using the 1-D models as opposed to the 2-D model. The temperature difference between the 1-D and 2-D models is less than $0.1^{\circ} \mathrm{C}$ at all monitored nodes.

Although the temperature profiles have been shown to be nearly identical for the 1-.D and 2-D models, they are not the most significant indicators of accuracy as far as the regulations (10 CFR 71) are concerned. Compliance with 10 CFR 71 is based primarily on the amount of heat added to the package. Therefore, the QTOTAL subroutine was used in conjunction with HEATING 7.1 to obtain a value for the total heat added to the package. The QTOTAL subroutine actually keeps track of all the heat energy transferred from the environment to the DT-18 package during the simulation. For the 2-D model, the value obtained from HEATING represents the actual amount of heat absorbed by the DT-18 package during the furnace test simulation. However, because of the way in which surface areas are calculated for 1-D models, the values obtained from HEATING for the 1-D models must be adjusted in order to compare them to the value from the 2-D model.

For the side model, the surface area used for calculations is

$$
\mathrm{A}_{\text {side }}=2 \pi \mathrm{rh}
$$

where $r$ is the radius and the height $(h)$ is 1.0 unit for a 1-D (r) model. Therefore, the heat that is actually absorbed by the sides of the DT-18 package is

$$
\mathrm{Q}_{\text {sido }}=\mathrm{Q}_{\text {sido, } 1 \cdot \mathrm{D}}(0.8317 / 1.0) \text {, }
$$

where 0.8317 represents the height of the DT-18 container in meters.

The surface area used for calculations for both the top and bottom of the package is

$$
A_{\text {top }}=A_{\text {bottom }}=\pi r^{2}
$$




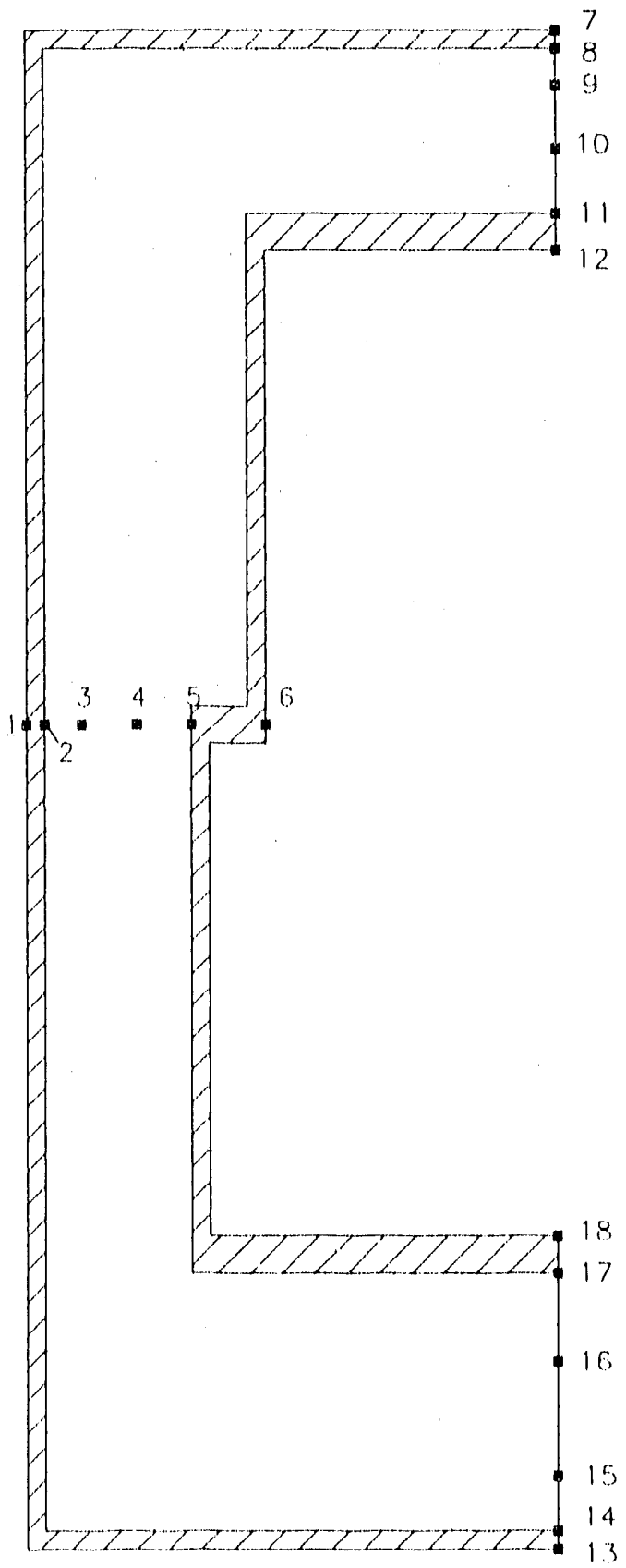

Fig. 4. Locations of DT-18 monitored temperatures. 
Table 4. Temperatures at selected locations in 1-D and 2-D DT-18 models

\begin{tabular}{|c|c|c|c|c|c|c|}
\hline \multirow[t]{2}{*}{ Location } & \multicolumn{6}{|c|}{$\begin{array}{c}\text { Temperature }\left({ }^{\circ} \mathrm{C}\right) \\
\text { 1-D } \\
\text { 2-D }\end{array}$} \\
\hline & $5 \mathrm{~min}$ & $10 \mathrm{mi}$. & $15 \mathrm{~min}$ & 20 min & $25 \mathrm{~min}$ & $30 \mathrm{~min}$ \\
\hline 1 & $\begin{array}{l}773.91 \\
773.91\end{array}$ & $\begin{array}{l}784.75 \\
784.75\end{array}$ & $\begin{array}{l}788.07 \\
788.07\end{array}$ & $\begin{array}{r}789.89 \\
789.89\end{array}$ & $\begin{array}{l}791.09 \\
791.09\end{array}$ & $\begin{array}{l}791.95 \\
791.95\end{array}$ \\
\hline 2 & $\begin{array}{l}773.63 \\
760.62\end{array}$ & $\begin{array}{l}784.57 \\
784.57\end{array}$ & $\begin{array}{l}787.93 \\
787.93\end{array}$ & $\begin{array}{l}789.78 \\
789.78\end{array}$ & $\begin{array}{l}790.98 \\
790.98\end{array}$ & $\begin{array}{r}791.85 \\
791.85\end{array}$ \\
\hline 3 & $\begin{array}{l}23.87 \\
23.89\end{array}$ & $\begin{array}{l}51.33 \\
51.32\end{array}$ & $\begin{array}{l}89.46 \\
89.44\end{array}$ & $\begin{array}{l}124.70 \\
124.70\end{array}$ & $\begin{array}{l}155.13 \\
155.12\end{array}$ & $\begin{array}{l}181.41 \\
181.41\end{array}$ \\
\hline 4 & $\begin{array}{l}21.11 \\
21.11 \\
\end{array}$ & $\begin{array}{l}21.14 \\
21.14 \\
\end{array}$ & $\begin{array}{l}21.68 \\
21.68 \\
\end{array}$ & $\begin{array}{l}23.76 \\
23.76 \\
\end{array}$ & $\begin{array}{l}27.90 \\
27.89\end{array}$ & $\begin{array}{l}33.89 \\
33.89\end{array}$ \\
\hline 5 & $\begin{array}{l}21.11 \\
21.11\end{array}$ & $\begin{array}{l}21.11 \\
21.11\end{array}$ & $\begin{array}{l}21.11 \\
21.11\end{array}$ & $\begin{array}{l}21.11 \\
21.11\end{array}$ & $\begin{array}{l}21.11 \\
21.12\end{array}$ & $\begin{array}{l}21.13 \\
21.14\end{array}$ \\
\hline 6 & $\begin{array}{l}21.11 \\
21.11\end{array}$ & $\begin{array}{l}21.11 \\
21.11\end{array}$ & $\begin{array}{l}21.11 \\
21.11\end{array}$ & $\begin{array}{l}21.11 \\
21.11\end{array}$ & $\begin{array}{l}21.11 \\
21.12\end{array}$ & $\begin{array}{l}21.12 \\
21.13\end{array}$ \\
\hline 7 & $\begin{array}{l}773.03 \\
773.01\end{array}$ & $\begin{array}{l}784.21 \\
784.22\end{array}$ & $\begin{array}{l}787.60 \\
787.60\end{array}$ & $\begin{array}{l}789.45 \\
789.45\end{array}$ & $\begin{array}{l}790.66 \\
790.66\end{array}$ & $\begin{array}{l}791.53 \\
791.53\end{array}$ \\
\hline 8 & $\begin{array}{l}772.73 \\
758.72 \\
\end{array}$ & $\begin{array}{l}784.03 \\
784.04 \\
\end{array}$ & $\begin{array}{r}787.45 \\
787.45 \\
\end{array}$ & $\begin{array}{r}789.32 \\
789.32 \\
\end{array}$ & $\begin{array}{l}790.55 \\
790.55 \\
\end{array}$ & $\begin{array}{l}791.43 \\
791.43 \\
\end{array}$ \\
\hline 9 & $\begin{array}{l}23.73 \\
23.74\end{array}$ & $\begin{array}{l}49.95 \\
49.94\end{array}$ & $\begin{array}{l}86.60 \\
86.60\end{array}$ & $\begin{array}{l}120.57 \\
120.58\end{array}$ & $\begin{array}{l}149.93 \\
149.93\end{array}$ & $\begin{array}{l}175.24 \\
175.23\end{array}$ \\
\hline 10 & $\begin{array}{l}21.11 \\
21.11\end{array}$ & $\begin{array}{l}21.11 \\
21.11\end{array}$ & $\begin{array}{l}21.15 \\
21.15 \\
\end{array}$ & $\begin{array}{l}21.43 \\
21.43 \\
\end{array}$ & $\begin{array}{l}22.30 \\
22.30 \\
\end{array}$ & $\begin{array}{l}24.00 \\
24.00 \\
\end{array}$ \\
\hline 11 & $\begin{array}{l}21.11 \\
21.11\end{array}$ & $\begin{array}{l}21.11 \\
21.11\end{array}$ & $\begin{array}{l}21.11 \\
21.11\end{array}$ & $\begin{array}{l}21.11 \\
21.11 \\
\end{array}$ & $\begin{array}{l}21.11 \\
21.11\end{array}$ & $\begin{array}{l}21.11 \\
21.11 \\
\end{array}$ \\
\hline 12 & $\begin{array}{l}21.11 \\
21.11\end{array}$ & $\begin{array}{l}21,11 \\
21,11\end{array}$ & $\begin{array}{l}21.11 \\
21.11\end{array}$ & $\begin{array}{l}21.11 \\
21.11\end{array}$ & $\begin{array}{l}21.11 \\
21.11\end{array}$ & $\begin{array}{l}21.11 \\
21.11\end{array}$ \\
\hline 13 & $\begin{array}{l}773.76 \\
773.74\end{array}$ & $\begin{array}{l}784.42 \\
784.42\end{array}$ & $\begin{array}{l}787.73 \\
787.73\end{array}$ & $\begin{array}{l}789.55 \\
789.55\end{array}$ & $\begin{array}{l}790.74 \\
790.74\end{array}$ & $\begin{array}{l}791.60 \\
791.60\end{array}$ \\
\hline
\end{tabular}


Table 4. (continued)

\begin{tabular}{|c|c|c|c|c|c|c|}
\hline \multirow[t]{2}{*}{ Location } & \multicolumn{6}{|c|}{$\begin{array}{c}\text { Temperature }\left({ }^{\circ} \mathrm{C}\right) \\
\text { 1-D } \\
\text { 2-D } \\
\end{array}$} \\
\hline & $5 \mathrm{~min}$ & $10 \mathrm{~min}$ & $15 \mathrm{~min}$ & $20 \mathrm{~min}$ & $25 \mathrm{~min}$ & $30 \mathrm{~min}$ \\
\hline 14 & $\begin{array}{l}773.47 \\
773.45\end{array}$ & $\begin{array}{l}784.24 \\
784.24\end{array}$ & $\begin{array}{l}787.59 \\
787.59\end{array}$ & $\begin{array}{l}789.43 \\
789.43\end{array}$ & $\begin{array}{l}790.64 \\
790.64\end{array}$ & $\begin{array}{l}791.50 \\
791.50\end{array}$ \\
\hline 15 & $\begin{array}{l}23.79 \\
23.79\end{array}$ & $\begin{array}{l}50.19 \\
50.18\end{array}$ & $\begin{array}{l}86.87 \\
86.87\end{array}$ & $\begin{array}{l}120.84 \\
120.83\end{array}$ & $\begin{array}{l}150.16 \\
150.15 \\
\end{array}$ & $\begin{array}{l}175.42 \\
175.42 \\
\end{array}$ \\
\hline 16 & $\begin{array}{l}21.11 \\
21.11\end{array}$ & $\begin{array}{l}21.11 \\
21.11\end{array}$ & $\begin{array}{l}21.11 \\
21.11\end{array}$ & $\begin{array}{l}21.11 \\
21.11\end{array}$ & $\begin{array}{l}21.13 \\
21.13\end{array}$ & $\begin{array}{l}21.19 \\
21.19\end{array}$ \\
\hline 17 & $\begin{array}{l}21.11 \\
21.11 \\
\end{array}$ & $\begin{array}{l}21.11 \\
21.11\end{array}$ & $\begin{array}{l}21.11 \\
21.11\end{array}$ & $\begin{array}{l}21.11 \\
21.11\end{array}$ & $\begin{array}{l}21.11 \\
21.11\end{array}$ & $\begin{array}{l}21.11 \\
21.11\end{array}$ \\
\hline 18 & $\begin{array}{l}21.11 \\
21.11\end{array}$ & $\begin{array}{l}21.11 \\
21.11\end{array}$ & $\begin{array}{l}21.11 \\
21.11\end{array}$ & $\begin{array}{l}21.11 \\
21.11\end{array}$ & $\begin{array}{l}21.11 \\
21.11\end{array}$ & $\begin{array}{l}21.11 \\
21.11\end{array}$ \\
\hline
\end{tabular}


where the radius (r) is 1.0 unit for a 1-D (z) model. Therefore, the actual value for the heat absorbed by the top of the DT-18 container can be approximated as

$$
Q_{\text {top }}=Q_{\text {top, } 1-1)}\left(0.2873^{2} / 1,0^{2}\right)
$$

where 0.2873 represents the radius, in meters, of the DT-18 container. Similarly, the actual value for the heat absorbed by the bottom of the DT- 18 container can be approximated as

$$
Q_{\text {bettom }}=Q_{\text {brottom, 1-1) }}\left(0.2873^{2} / 1.0^{2}\right) \text {. }
$$

The total heat added to the DT-18 package can be approximated from values obtained from the 1-D models as follows:

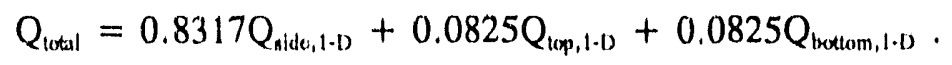

The values obtained for the total heat added to the DT-18 package from the 1-D and 2-D models are presented in tabular form in Table 5. The results from the 1-D models are slightly higher (about $2 \%$ maximum) than those from the 2-D model. This difference is expected since the 1-D models neglect edge effects. Thus, an effective method for modeling the DT-18 shipping package during thermal testing is to make use of three 1-D models. The results from the 1-D models can then be normalized based on the 2-D results for Case 1 presented in Table 5. The largest variation between the results of the 1-D and 2-D models for Case 1 is $1.8 \%$ at a time of $30 \mathrm{~min}$. Thus, it would be slightly conservative to normalize all 1-D case values by $1.8 \%$ (i.e., multiply all HEATING 7.1 1-D values by a factor of 0.983 ). In this manner ccnservative and accurate calculations of the total heat input to DT-18 packages under various conditions can be obtained without prohibitively long computer run times. 
Table 5. Comparison of total heat added to DT-18 package for 1-D and 2-D models

\begin{tabular}{|c|c|c|c|}
\hline \multirow{2}{*}{$\begin{array}{c}\text { Time } \\
(\text { min) }\end{array}$} & Total heat added $(\boldsymbol{J})$ & $\begin{array}{c}\text { Percent } \\
\text { difference }\end{array}$ \\
\cline { 2 - 4 } & 1-D model & 2-D model & 0.066 \\
\hline \hline 1 & $6,568,259$ & $6,563,901$ & 0.201 \\
\hline 3 & $10,615,247$ & $10,593,950$ & 0.375 \\
\hline 4 & $12,554,114$ & $12,507,170$ & 0.412 \\
\hline 5 & $13,606,358$ & $13,550,590$ & 0.540 \\
\hline 10 & $14,332,209$ & $14,255,290$ & 0.874 \\
\hline 15 & $16,704,223$ & $16,559,478$ & 1.138 \\
\hline 20 & $18,378,841$ & $18,172,062$ & 1.367 \\
\hline 25 & $19,752,597$ & $19,486,159$ & 1.581 \\
\hline 30 & $20,945,949$ & $20,619,944$ & 1.775 \\
\hline
\end{tabular}




\section{DISCUSSION OF RESULTS}

By performing thermal analyses for several different cases, the effects of numerous variables on the total heat received by a package can be studied. In particular, two variables, radiating temperature (furnace surface temperature) and gray-body interchange factor, were examined in-depth. The result is a parametric study involving these two variables and how they affect the total heat received by the D'T-18 package.

\section{Effect of Gray-Body Interchange Factor}

The gray-body interchange factor has received a great deal of attention during recent attempts to finalize acceptable thermal testing procedures. Given this attention, it is very interesting to find that the effect of the interchange factor over a 30-min fire test of a DT-18 package is not as significant as one might think. Figure 5 shows the total heat energy (in joules) that would be imparted to a DT-18 package during a 30-min furnace test for several different gray-body interchange factors over a range of furnace surface temperatures. This figure indicates that during a fire test, for this type of package, the interchange factor can change by $100 \%$ (from 0.4 to 0.8 ) and the change in total heat to the package differs by only about $2 \%$. Table 6 contains data that demonstrate how varying the interchange factor and the furnace radiating temperature affect the heat supplied to the package when compared to regulatory requirements. These data lead to a very important conclusion about the D'T-18 package and other packages that are similarly constructed of thin steel shells using Celotex ${ }^{\mathrm{TM}}$ as an impact absorber and thermal insulator. That is, for prolonged exposure to thermal insult, the quantity of heat that enters such a package is more dependent on the boundary temperature than on the quality of the boundary condition (i.e., gray-body interchange factor). This conclusion is based on the fact that the Celotex ${ }^{\mathrm{TM}}$ insulation material possesses an extremely low thermal conductivity and the outer container shell nas very little heat storage capacity. Thus, when a package is placed in a furnace (or ex ${ }_{1}^{-}$) sed to any other thermal source), the outer container of the package, which is constructed of stainless steel and possesses a much greater thermal conductivity than does Celotex ${ }^{\mathrm{TM}}$, heats up quickly. However, this heat energy is not readily passed into the package because of the low thermal diffusivity of the Celotex ${ }^{\mathrm{rM}}$. Therefore, the temperature of the outer container approaches the temperature of the surroundings very quickly. If the material inside the outer container were more conductive, the heat would diffuse into the package and the temperature on the outside of the package would not rise as quickly. Likewise, if the outer container shell were thicker, more energy would be needed to heat the greater mass, and the outer surface temperature of the package would not rise as quickly.

For Case 4 (0.8 interchange factor and $800^{\circ} \mathrm{C}$ radiating temperature), the rate of radiative heat transfer at the onset of the thermal test is very high (see Eq. 2), which in turn raises the temperature of the outer container very rapidly. From Eq. 2 it is obvious that the rate of radiative heat transfer subsides greatly as $T_{p}$, the package surface temperature, increases (see Fig. 6). Conversely, for Case 2 (interchange factor of 0.4 and $800^{\circ} \mathrm{C}$ radiating temperature), at the initiation of the thermal test the rate of heat transfer is only about one half that of Case 4 . However, this is true only at the very beginning of the test. Because Case 2 does not absorb as much heat at the onset, the outer container temperature does not increase as quickly as it does for Case 4. Again, examination of Eq. 2 shows that the rate of radiative heat transfer is much more dependent on $T_{p}$ than it is on the interchange factor. Thus, shortly into the test, Case 2 is 


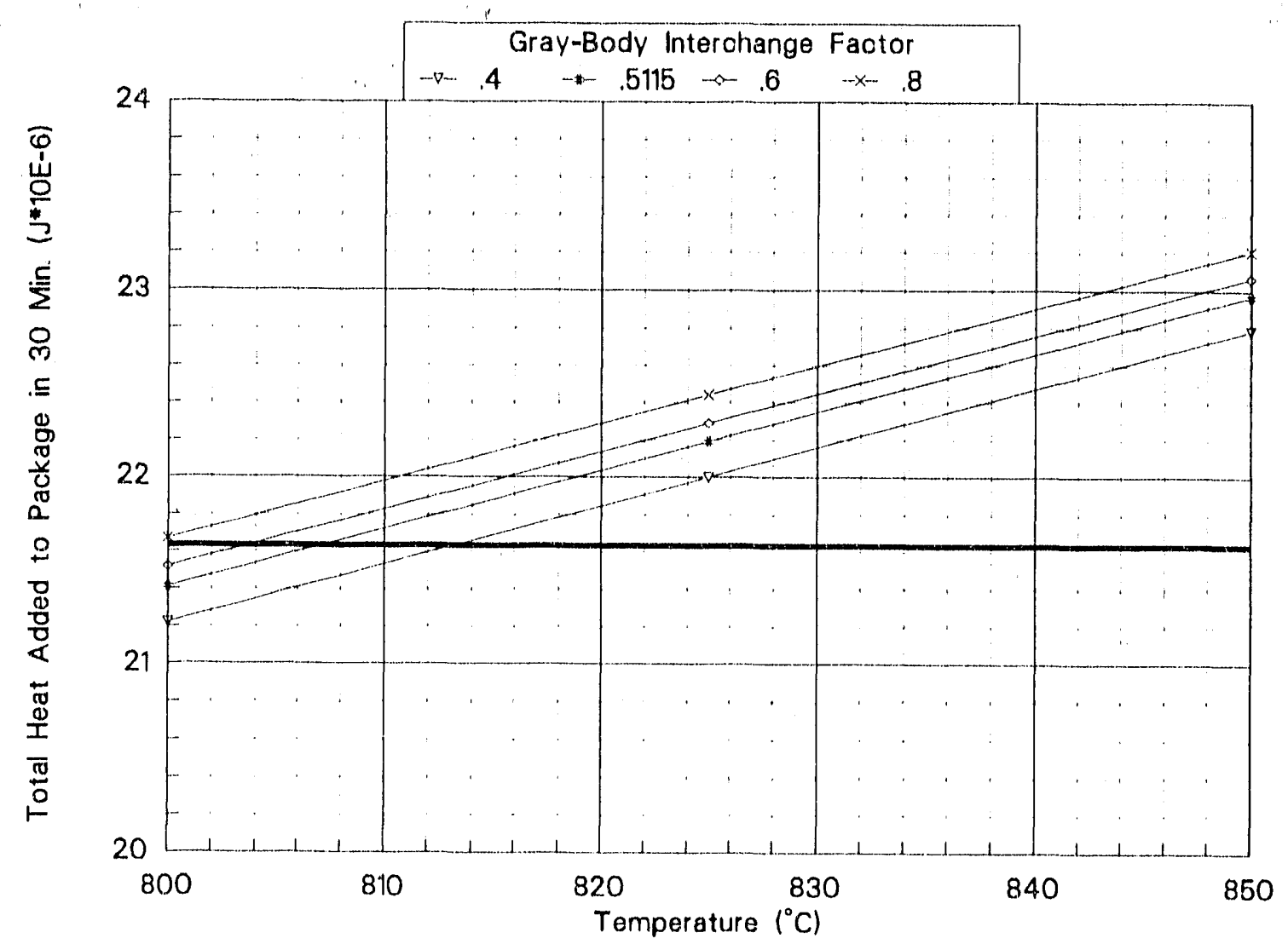

Fig. 5. Effect of environment temperarure on the total heat added to the DT-18 package for various gray-body interchange factors. Solid line indicates regulatory heat flux. 
Table 6. Total heat added to DT-18 package

\begin{tabular}{|c|c|c|c|c|}
\hline Case & $F$ & $\mathbf{T}_{\text {rutiating }}$ & $\begin{array}{c}\text { Total heat } \\
\text { added }(\mathbf{J})^{a}\end{array}$ & $\begin{array}{c}\text { Percent of heat } \\
\text { required by 10 CFR 71 }\end{array}$ \\
\hline 1 & 0.7347 & $800^{\circ} \mathrm{C}$ & $2.163 \mathrm{E}+07$ & $100.0 \%$ \\
\hline 2 & 0.4 & $800^{\circ} \mathrm{C}$ & $2.122 \mathrm{E}+07$ & $98.10 \%$ \\
\hline 3 & 0.6 & $800^{\circ} \mathrm{C}$ & $2.152 \mathrm{E}+07$ & $99.49 \%$ \\
\hline 4 & 0.8 & $800^{\circ} \mathrm{C}$ & $2.167 \mathrm{E}+07$ & $100.2 \%$ \\
\hline 5 & 0.4 & $825^{\circ} \mathrm{C}$ & $2.200 \mathrm{E}+07$ & $101.7 \%$ \\
\hline 5 & 0.6 & $825^{\circ} \mathrm{C}$ & $2.229 \mathrm{E}+07$ & $103.1 \%$ \\
\hline 7 & 0.8 & $825^{\circ} \mathrm{C}$ & $2.244 \mathrm{E}+07$ & $103.7 \%$ \\
\hline 8 & 0.4 & $850^{\circ} \mathrm{C}$ & $2.279 \mathrm{E}+07$ & $105.3 \%$ \\
\hline 9 & 0.6 & $850^{\circ} \mathrm{C}$ & $2.307 \mathrm{E}+07$ & $106.7 \%$ \\
\hline 10 & 0.8 & $850^{\circ} \mathrm{C}$ & $2.321 \mathrm{E}+07$ & $107.3 \%$ \\
\hline 11 & 0.5115 & $800^{\circ} \mathrm{C}$ & $2.141 \mathrm{E}+07$ & $99.01 \%$ \\
\hline 12 & 0.5115 & $825^{\circ} \mathrm{C}$ & $2.219 \mathrm{E}+07$ & $102.6 \%$ \\
\hline 13 & 0.5115 & $850^{\circ} \mathrm{C}$ & $2.297 \mathrm{E}+07$ & $106.2 \%$ \\
\hline
\end{tabular}

" Values are normalized as described on page 19. 


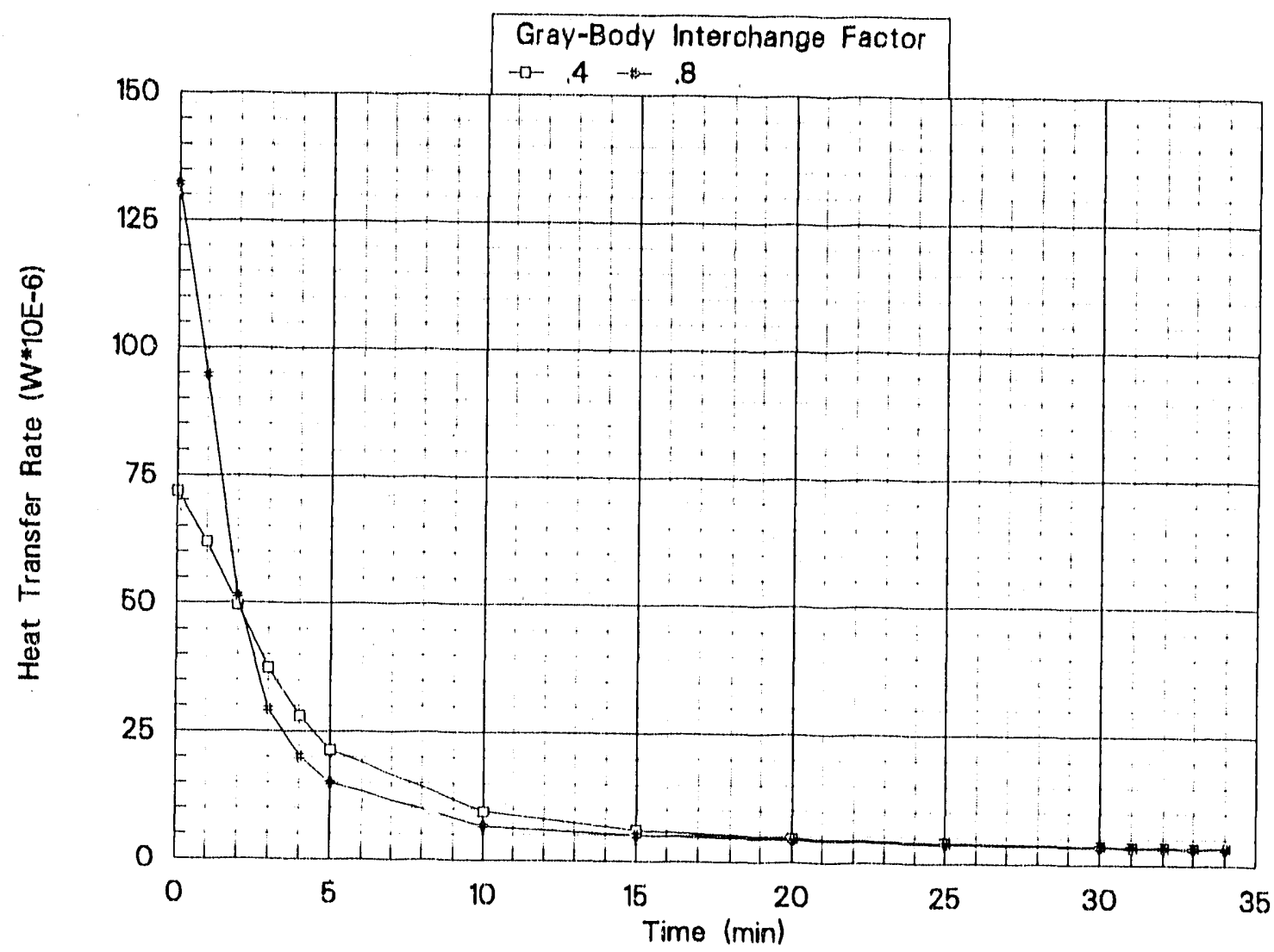

Fig. 6. Transient heating rate curve for the DT-18 package when exposed to an $800^{\circ} \mathrm{C}$ environment for various gray-body interchange factors. 
actually absorbing more heat per time than is Case 4 (see Fig. 6). The outcome of this situation is that during the first few minutes of the test, Case 4 absorbs mach more heat than does Case 2 . However, after these initial few minutes, Case 2 is actually absorbing heat at a faster rate than is $\mathrm{C}$ ise 4 , and this condition continues for the duration of the test.

To ensure that the reader is not misled, it should be stated that at no time will the net total heat added for Case 2 exceed the value for Case 4 . However, it will very nearly approach it after a period of time, as in this instance where Case 2 is within $2.1 \%$ of Case 4 after 30 min. Thus, it is clear that; although the interchange factor is important when considering initial heating rates, it is not as significant when considering the total amount of heat energy that is added to a thin-shelled Celotex ${ }^{\mathrm{TM}}$-based package during a 30 -min fire test in an $800^{\circ} \mathrm{C}$ furnace. This total (net) amount of heat energy that is added to the package is the quantity with which 10 CFR 71 is concerned, and thus is the quantity upon which certification of thermal testing should be based.

The cases compared in the preceding discussion have interchange factors of 0.4 and 0.8 , whereas 10 CFR 71 (Case 1) calls for an interchange factor of 0.7347 . The B-1023 furnace/DT-18 package scenario (Case 11) has an interchange factor value of 0.5115 . Thus the difference in heat added during $30 \mathrm{~min}$ would be less than $2 \%$. In fact, Table 6 indicates that the difference in heat added is slightly less than $1 \%$.

\section{Effect of Radiating Temperature}

To date, the guidance received from DOE/AL concerning the running of thermal tests has been based on changing the furnace surface temperature to compensate for furnace emissivity and package absorptivity and seems to conflict with the standards specitied in 10 CFR 71. This guidance has consistently considered only the heat flux at a particular instant rather than the effect throughout the duration of the test. Figure 7 shows the total heat energy (in joules) that would be imparted to a DT-18 package during a 30-min furnace test for several different furnace surface temperatures over a range of gray-body interchange factors. (Note: the data displayed here are taken from Table 6 and are the same as the data displayed in Fig. 5.) It is quite obvious that small changes in furnace surface temperature have a significant impact on the total heat imparted to a container during a thermal test. The guidance that has been received from DOE/AL could easily result in the setting of furnace temperatures that lead to as much as $7.3 \%$ more heat being added to a package than is actually called for in 10 CFR 71 . There is no doubt that such a quantity of heat energy would constitute a severe overtest of a shipping package. 


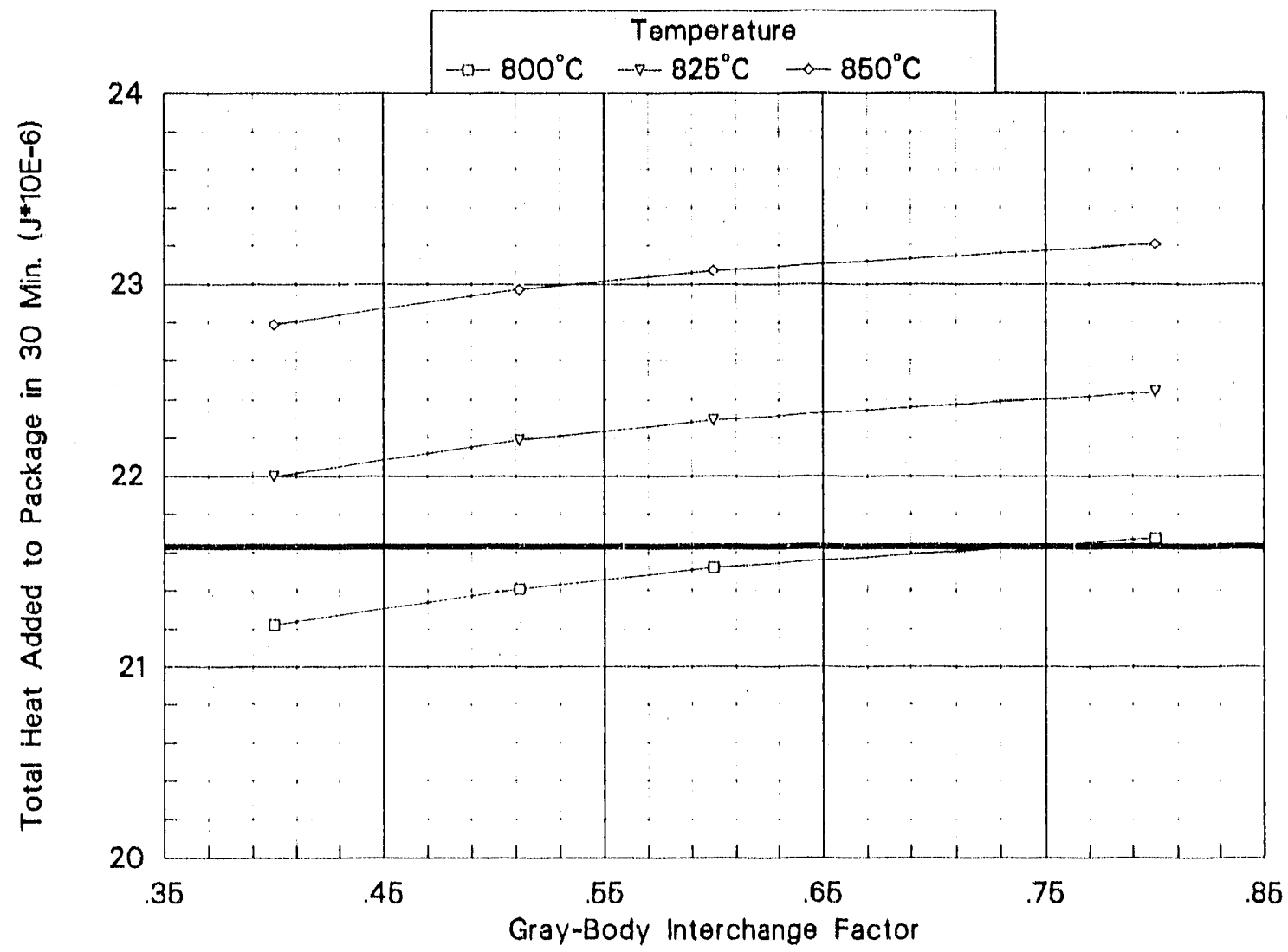

Fig. 7. Effect of gray-body interchange factor on the total heat added to the DT-18 package for various environment temperatures. Solid line indicates regulatory heat flux. 


\section{RECOMMENDATIONS}

The results of the analyses presented in this report should be used to devise a more simplified method of thermal testing which would produce tests that undoubtedly comply with 10 CFR 71 while not resulting in a severe overtest. One of two very simple approaches using the data presented above should be used in future testing to ensure that these objectives are met. From Fig. 5 it is very easy to determine the temperature that the furnace surface would have to maintain for the total heat added to the package to equal that required in $10 \mathrm{CFR} 71$. If this temperature were specified as a minimum furnace surface temperature, the test would be conservative in nature. Since small temperature gradients exist across the furnace, all furnace surface temperatures would be at or above this specified temperature.

The second alternative method would be to keep the minimum furnace surface temperature at $800^{\circ} \mathrm{C}$ and allow the package to remain in the furnace for a time beyond the required 30 min. Figures 8 and 9 show the heat energy input to a DT-18 package as a function of time for various interchange factors and a radiating temperature of $800^{\circ} \mathrm{C}$. The solid line indicates the quantity of heat energy required by 10 CFR 71. Table 7 contains the values of time required for a DT. 18 package to receive the heat required by 10 CFR 71 for the range of interchange factors and radiating temperatures considered in this study. It is evident that DT-18 packages left in the B-1023 furnace $(F=0.5115)$ for approximately $31 \mathrm{~min}(1 \mathrm{~min}$ extra) would meet the requirements of $10 \mathrm{CFR} 71$. 


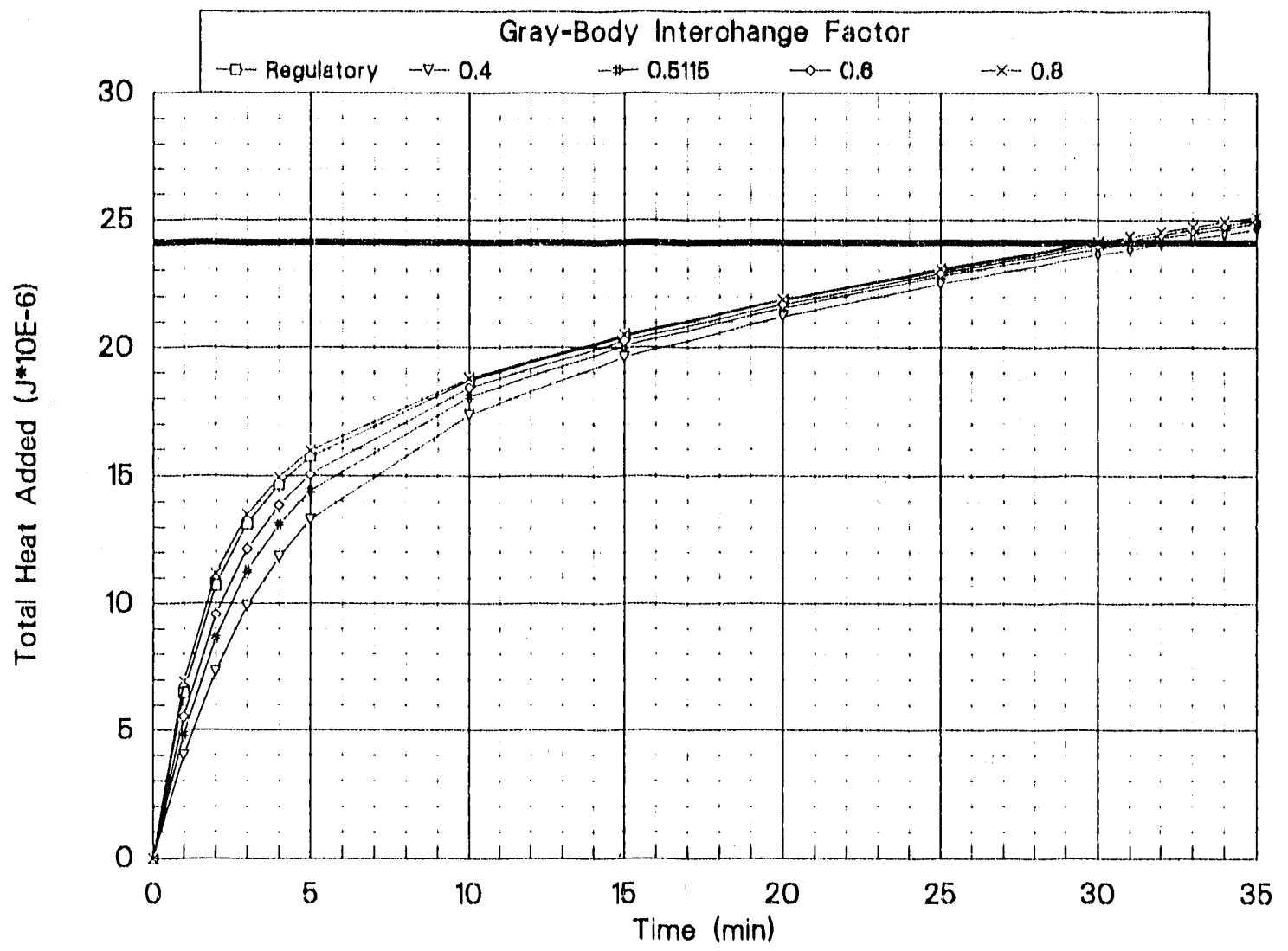

Fig. 8. Net heat added to the DT-18 package when exposed to an $800^{\circ} \mathrm{C}$ environment as a function of time. Solid line indicates regulatory heat flux. 


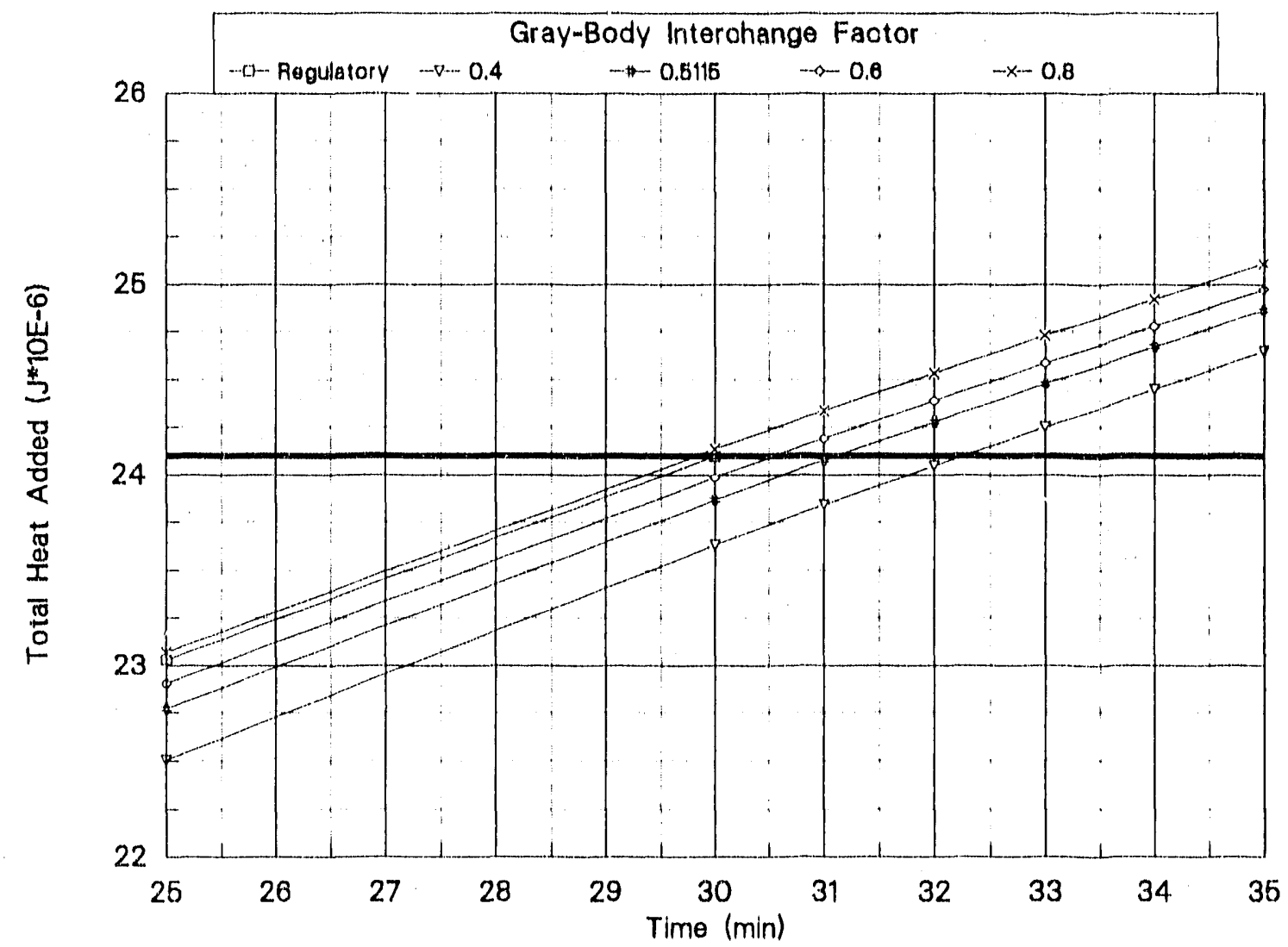

Fig. 9. Net heat added to the D'T-18 package when exposed to an $800^{\circ} \mathrm{C}$ environment as a function of time. Close-up of a portion of Fig. 8, solid line indicates regulatory heat flux. 
Table 7. Time required for D'T-18 package to receive heat required by 10 CFR 71

\begin{tabular}{|c||c|c|c|}
\hline \multirow{2}{*}{$\begin{array}{c}\text { Interchange } \\
\text { Factor }\end{array}$} & \multicolumn{3}{|c|}{ Radiating Temperature } \\
\cline { 2 - 4 } & $\mathbf{8 0 0 ^ { \circ } \mathrm { C }}$ & $\mathbf{8 2 5 ^ { \circ } \mathbf { C }}$ & $\mathbf{8 5 0 ^ { \circ } \mathbf { C }}$ \\
\hline 0.4 & $32 \mathrm{~min}$ & $28.25 \mathrm{~min}$ & $25 \mathrm{~min}$ \\
\hline 0.5115 & $31 \mathrm{~min}$ & $27.5 \mathrm{~min}$ & $24 \mathrm{~min}$ \\
\hline 0.6 & $30.5 \mathrm{~min}$ & $27 \mathrm{~min}$ & $23.75 \mathrm{~min}$ \\
\hline 0.8 & $30 \mathrm{~min}$ & $26.25 \mathrm{~min}$ & $23 \mathrm{~min}$ \\
\hline
\end{tabular}




\section{CONCLUSIONS}

A method of analytical thermal modeling has been doveloped to calculate the quantity of heat energy input to which a DT-18 package is exposed during a hypothetical thermal accident scenario test. Though the modeling capabilities developed to date do not fully account for the thermal activity within the package, they do properly calculate the amount of heat that would he imparted to a DT-18 package when it is thermally tested. The results indicate that, due to the nature of the Celotex ${ }^{T M}$-based packaging technology (or other packaging that employs a thin metal outer shell enclosing a thermally insulating material), the gray-body interchange factor is not the most significant consideration in determining the quantity of heat imparted to a package during a severe thermal insult.

The discrepancy in the gray-body interchange factor which is specified by 10 CFR 71 and which actually exists in the B-1023 furnace during a DT-18 thermal test causes the DT-18 package to receive about $1 \%$ less heat energy than that required by federal regulations. Simple methods for correcting this difference include either slightly raising the minimum furnace surface temperature during a test or allowing the package to remain in the furnace for a time slightly exceeding the specified 30-min period. The two techniques suggested above represent methods of hypothetical thermal accident testing that would allow for more simplified testing while also ensuring that the test procedure is more in the spirit of the federal regulations. These new methods of testing do require more technical rigor to arrive at proper methods for hypothetical thermal accident testing than does a method that employs only a single data point (i.e., only considering the radiative heat transfer rate at the initiation of the thermal test). However, these new methods ensure that future tests will comply with federal regulations without exposing the package to severe overtest conditions. 


\section{REFERENCES}

1. Packaging and Transportation of Radloactive Materials, U.S. Nuclear Regulatory Commission, Title 10, Code of Federal Regulations, Part 71, 1987.

2. K. W. Childs, HEAT7NG 7.1 User's' Manual, K/CSD/TM-96, 1991.

3. R. Siegel and J, R. Howell, Thermal Radiation Heat Transfer, Hemisphere Publishing Corporation, NY, 1981.

4. F. P. Incropera and D, P. DeWitt, Fundamentals of Heat and Mass Transfer, John Wiley \& Sons, NY, 1985.

5. M. R. Feldman, Characterization of the B-1023 Furnace for Use in Hypothetical Thermal Accident Testing of Shipping Containers In Accordance with $10 \mathrm{CFR}$, Part 71, ORNL/ENG-10, January 1992. 
APPENDICES 


\section{APPENDIX 1 \\ TWO-DIMENSIONAL, DT-18 HEATING MODEL.}

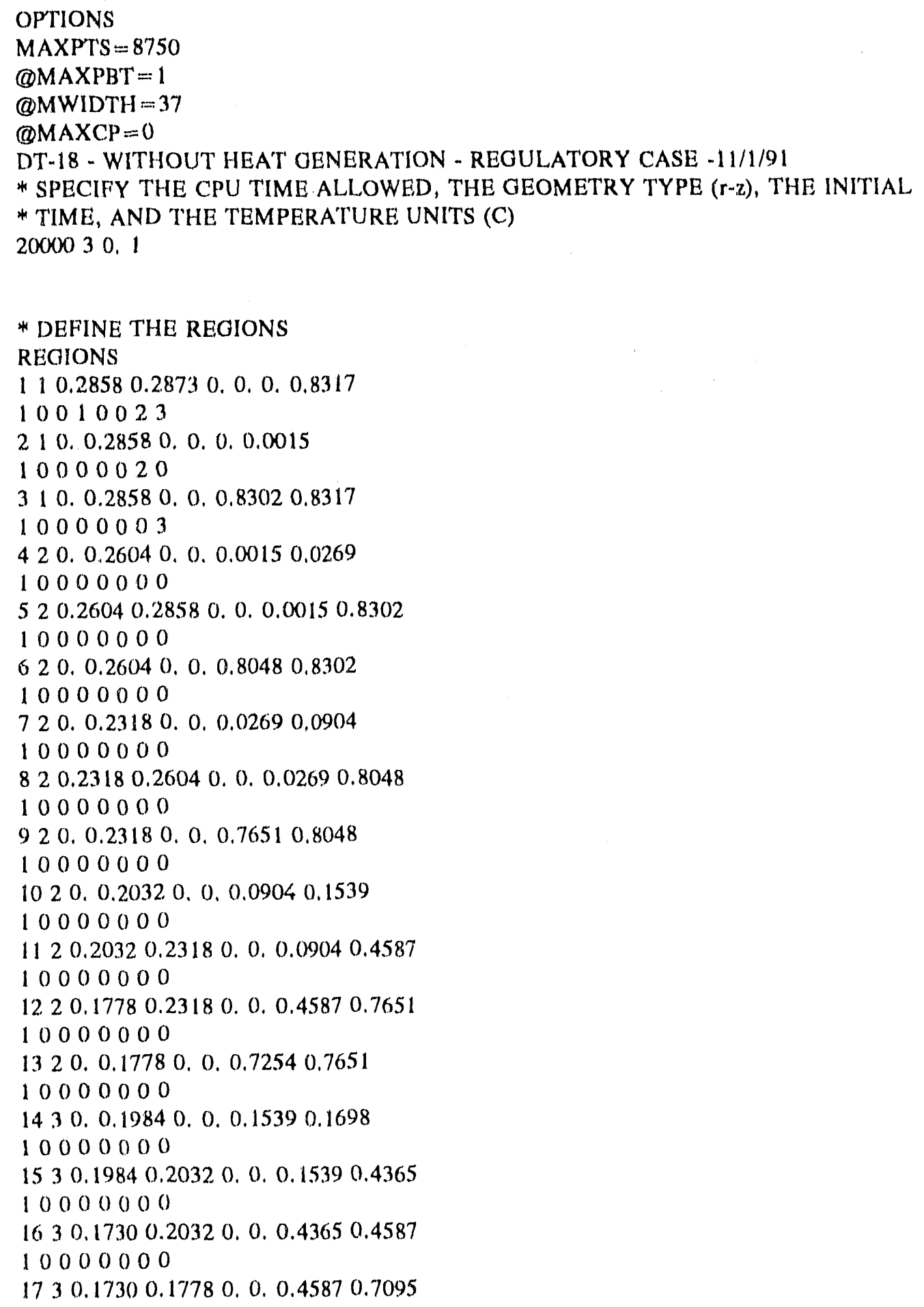


10000000

1830.0 .17780 .0 .0 .70950 .7254

10000000

* DEFINE THE MATERIALS USED IN THE MODEL

MATERIALS

1 STEEL1 $179001-10-20$

2 CELOTEX $11270 \begin{array}{llllll}1 & -3 & 0 & -4 & 0\end{array}$

3 STEEL2 $179001-10-20$

* SPECIFY THE INITIAL TEMPERATURES

INITIAL TEMPERATURES

121.11

* SPECIFY THE BOUNDARY CONDITIONS

BOUNDARY CONDITIONS

$110.0-5000$

0.01 .01 .370 .250 .01

$0-80000$

$210.0-600 \mathrm{C}$

0.01 .01 .00 .250 .01

$0-9-1000$

$310.0-70000$

0.01 .01 .00 .250 .01

$0-11-1200$

* ESTABLISH THE NODE SPACING IN THE X (r) DIRECTION

XGRID

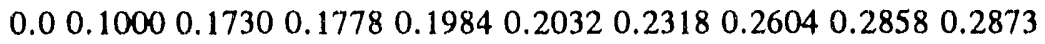

161113159161

* ESTABLISH THE NODE SPACING IN THE Z DIRECTION

ZGRID

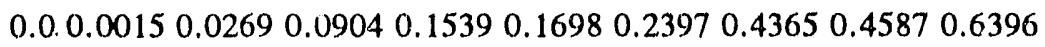

$@ 0.70950 .72540 .76510 .80480 .83020 .8317$

116201031131328113613161

TABULAR FUNCTIONS

* ENTER THE THERMAL CONDUCTIVITY DATA FOR STAINLESS STEEL

1

$-7312.6$

@27 14.9

(3)127 16.6

(Q)327 19.8

(a) 52722.6

@727 25.4

(1692728.0

* ENTER THE SPECIFIC HEAT DATA FOR STAINLESS STEEL

2

$-73402$

@27 477

(10127515

@327 557

@527 582

@727 611

@927 040 


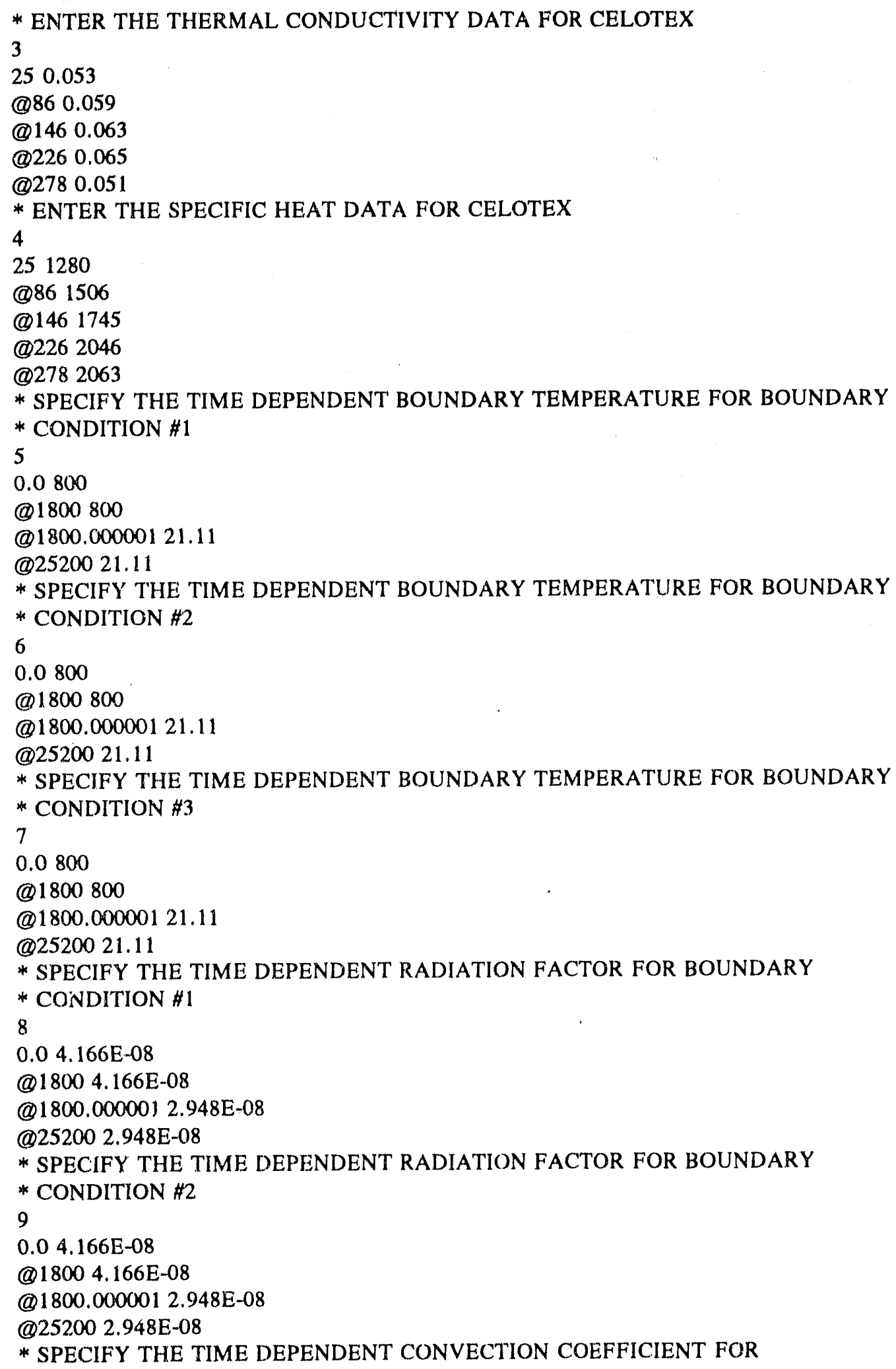




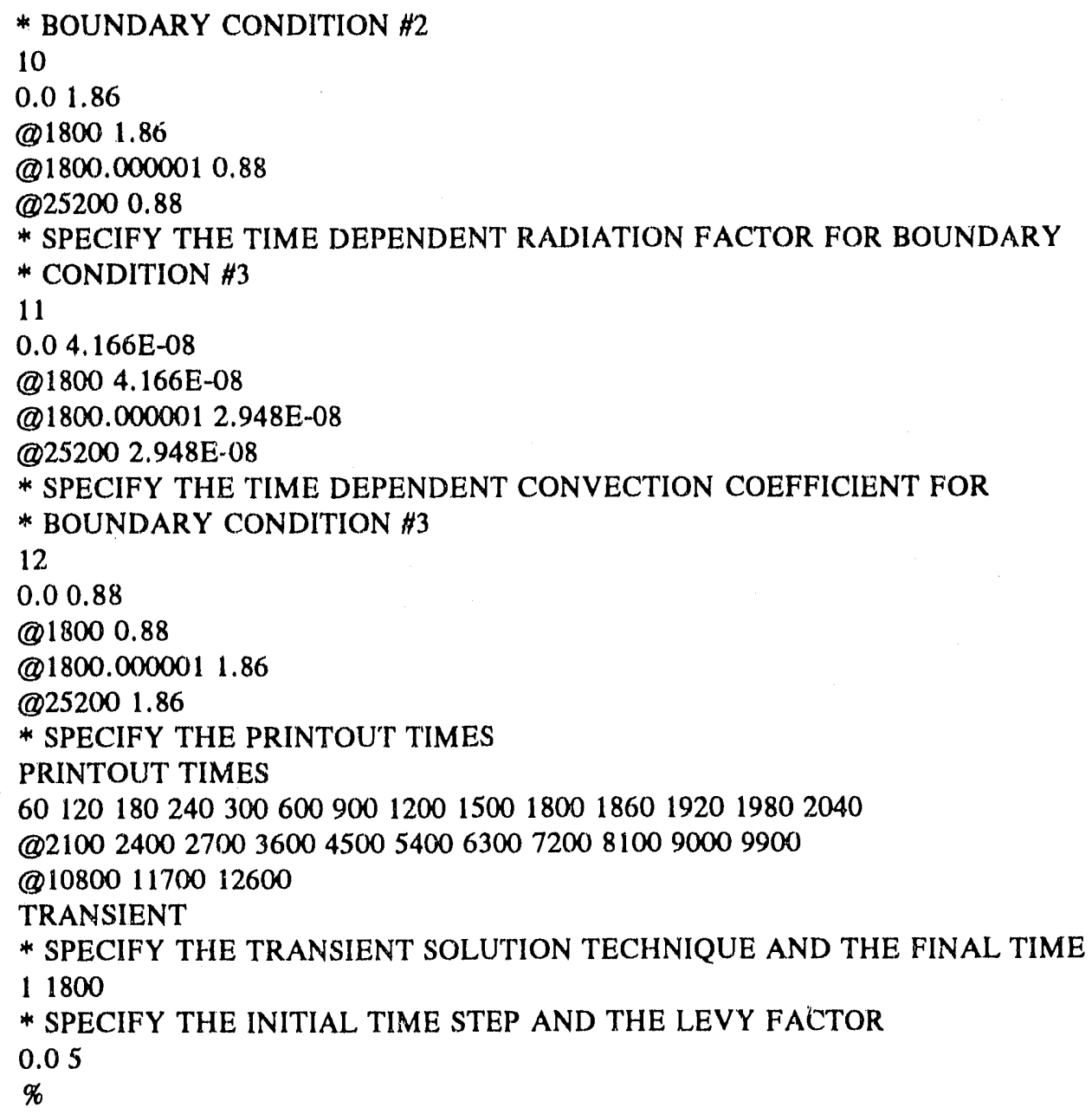




\section{APPENDIX 2 \\ ONE-DIMENSIONAL DT-18 HEATING MODEL - SIDE}

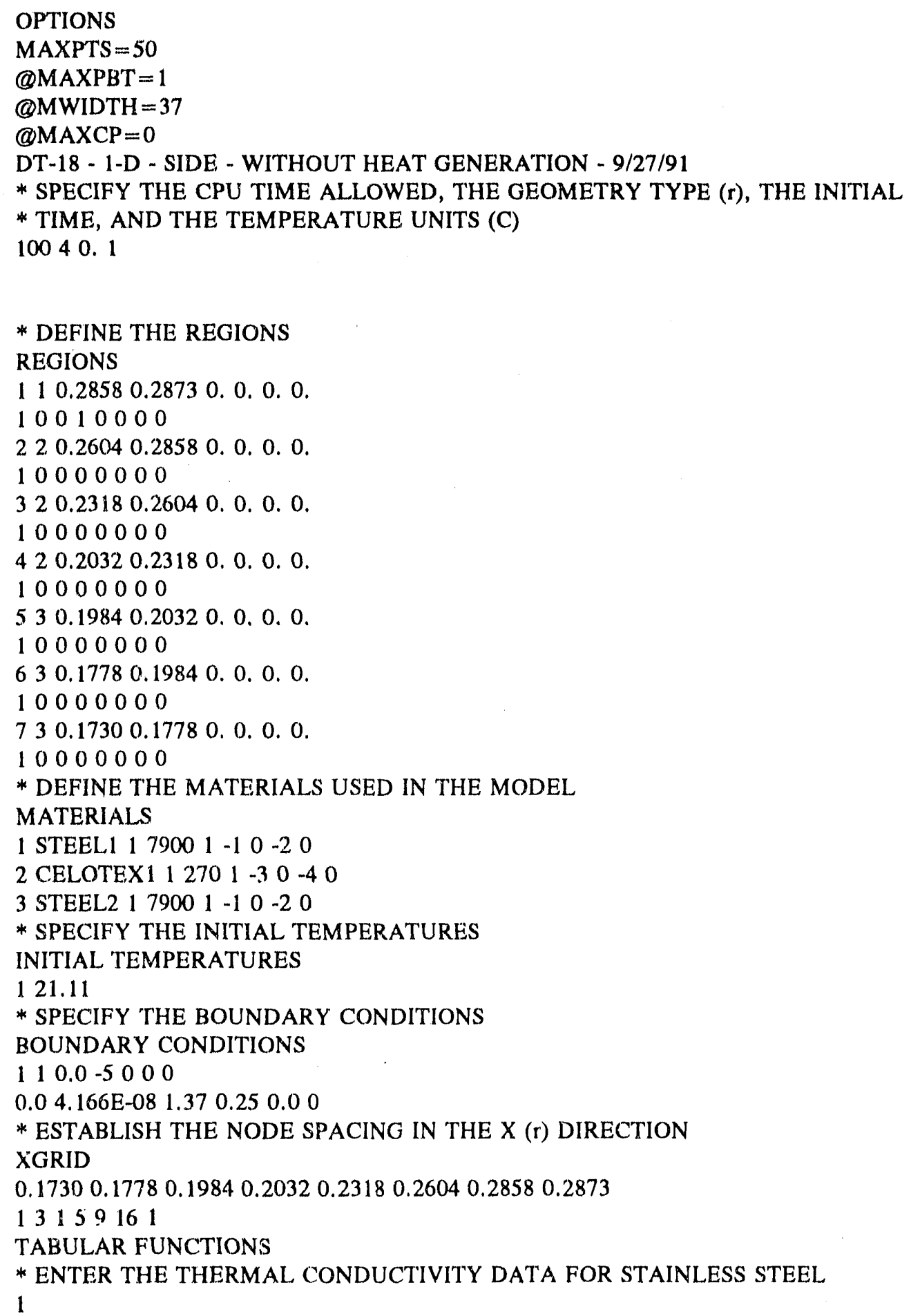




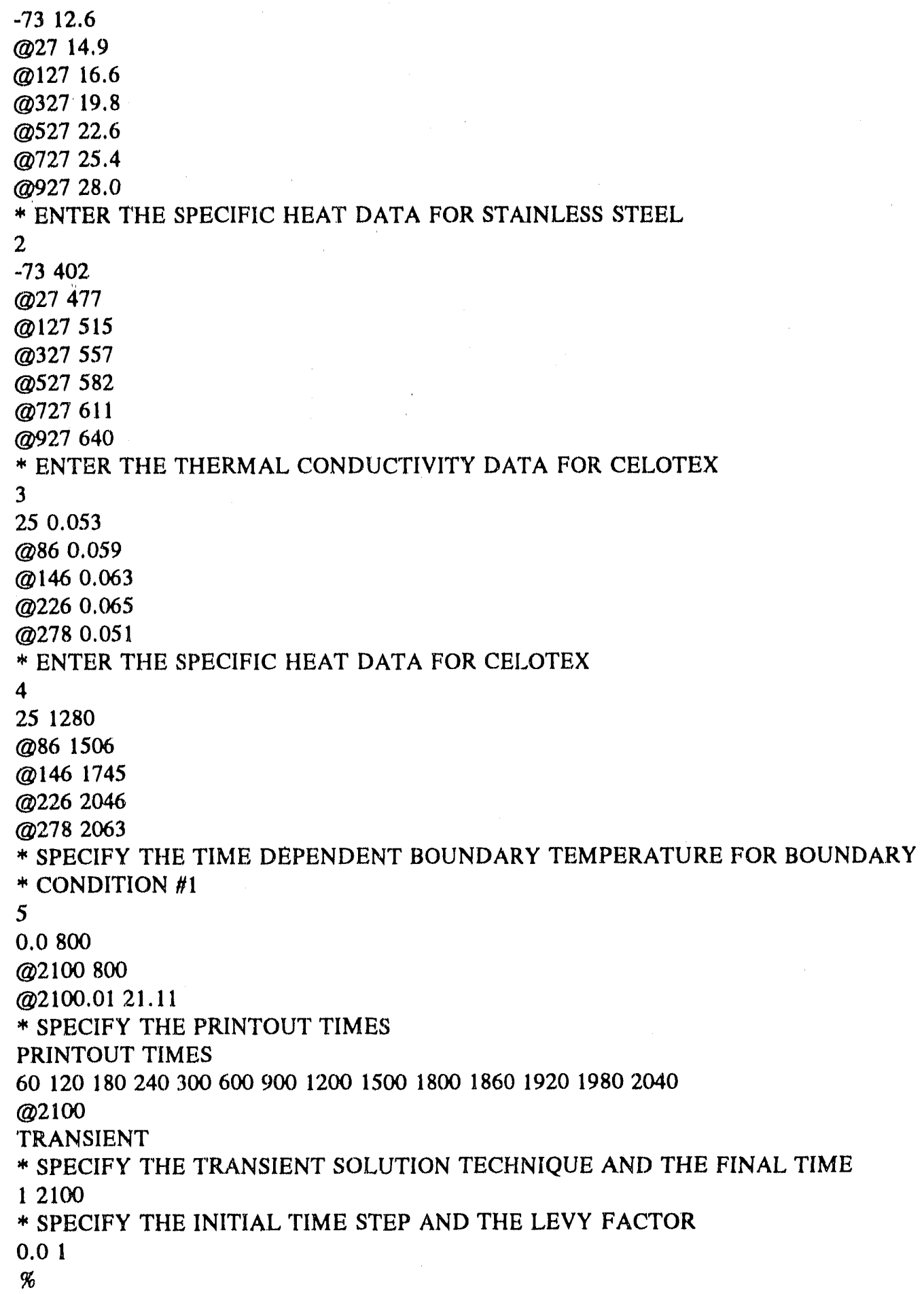


APPENDIX 3

ONE-DIMENSIONAL DT-18 HEATING MODEL - TOP

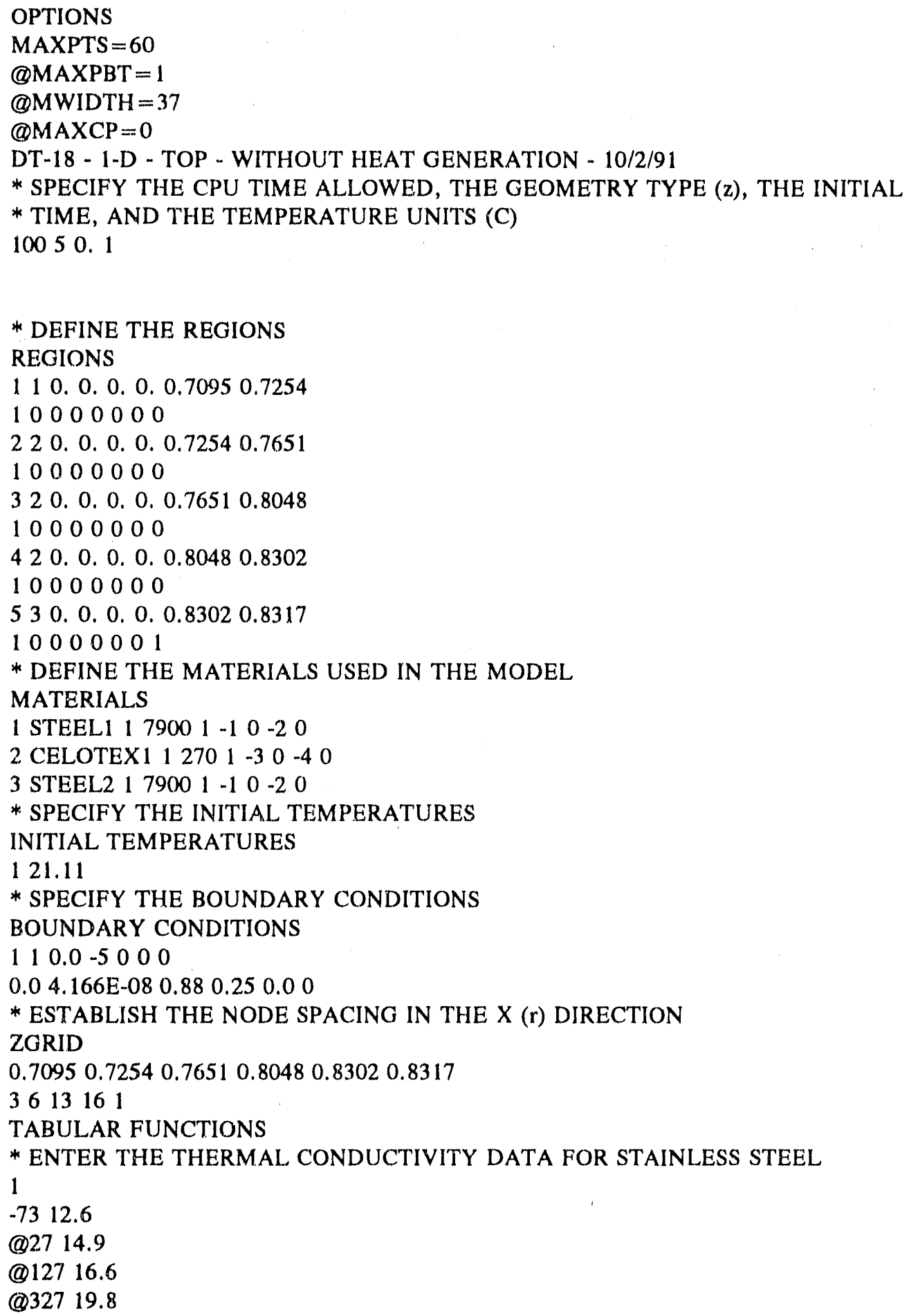




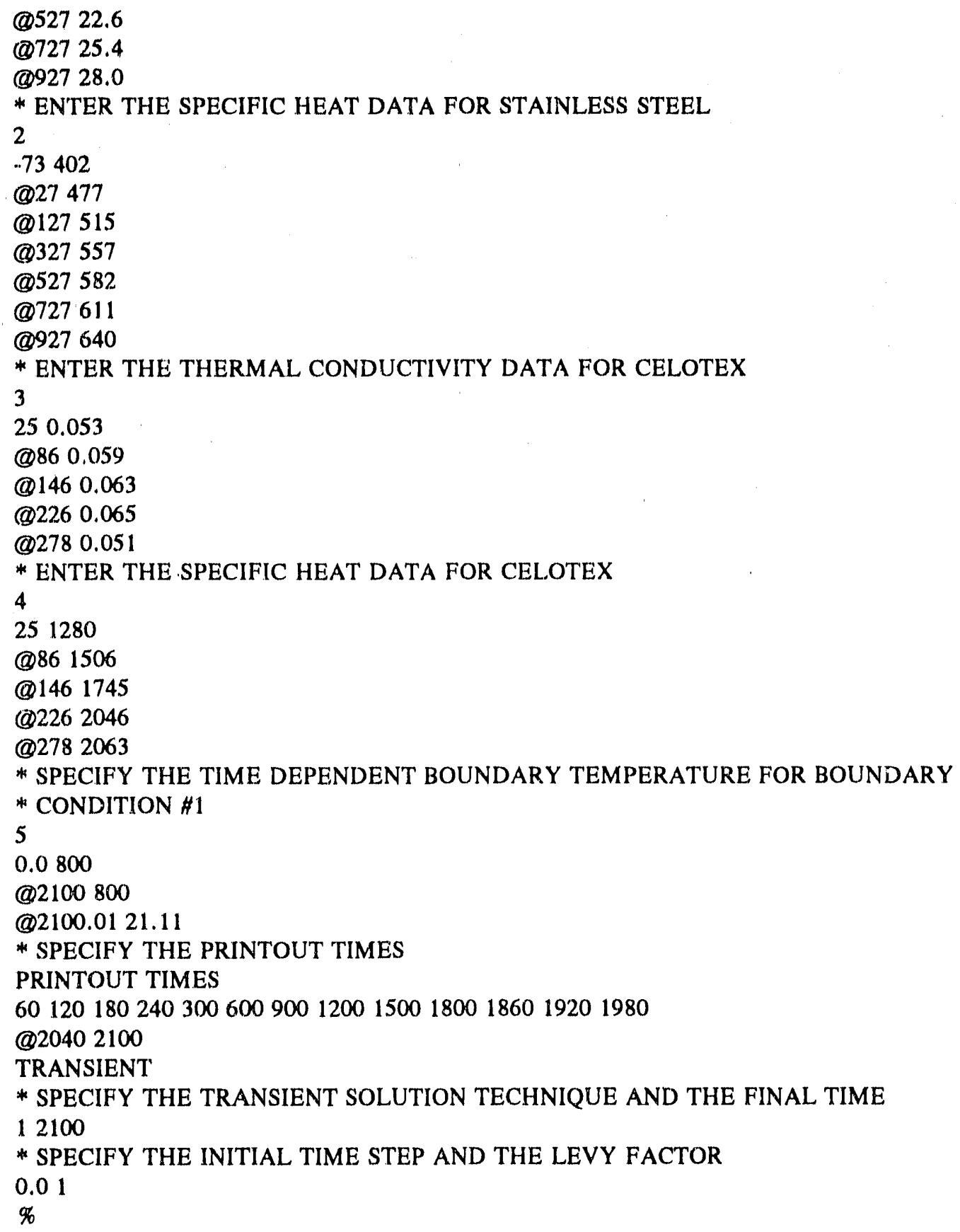




\section{APPENDIX 4 \\ ONE-DIMENSIONAL DT-18 HEATING MODEL - BOTTOM}

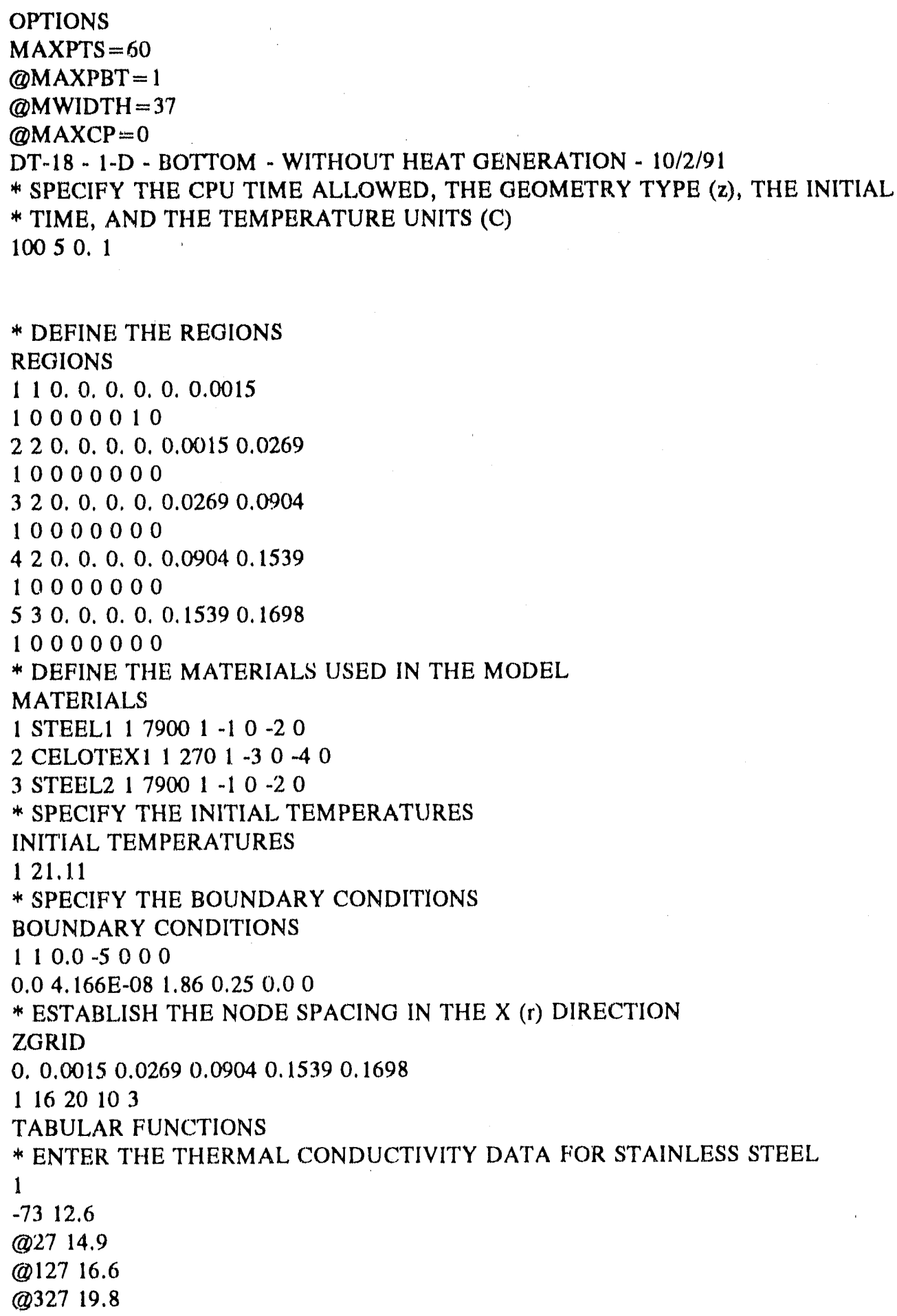


@527 22.6

@72725.4

@927 28.0

* ENTER THE SPECIFIC HEAT DATA FOR STAINLESS STEEL

2

.73402

(Q2) 2747

(@127515

@327 557

(c)527582

@727 611

(C)927 640

* ENTER THE THERMAL CONDUCTIVITY DAT'A FOR CELOTEX 3

250.053

@860.059

(a) 1460.063

@226 0.065

@278 0.051

* ENTER THE SPECIFIC HEAT DATA FOR CELOTEX

4

251280

(18861506

(6) 1461745

(@)2262046

@278 2063

* SPECIFY THE TIME DEPENDENT BOUNDARY TEMPERATURE FOR BOUNDARY

* CONDITION \#1

5

0.0800

@2100800

@2.100.00000: 21.11

* SPECIFY THE PRINTOUT TIMES

PRINTOUT TIMES

60120180240300600900120015001800186019201980

@2040 2100

TRANSIENT

* SPECIFY THE TRANSIENT SOLUTION TECHNIQUE AND THE FINAL TIME

12100

* SPECIFY THE INITIAL TIME STEP AND THE LEVY FACT'OR

0.01

$\%$ 


\section{INTERNAL DISTRIBUTION}

$\begin{aligned} 1-5 . & \text { J. C. Anderson } \\ 6 . & \text { H. C. Beeson } \\ 7 . & \text { J. P. Belk } \\ 8 . & \text { R. W. Bieniek } \\ 9 . & \text { B. B. Bowden } \\ 10 . & \text { J. R. Dixon } \\ 11 . & \text { D. A. Dyslin } \\ 12 . & \text { B. F. Elam } \\ \text { 13-17. } & \text { M. R. Feldman } \\ 18 . & \text { C. P. Frew } \\ 19 . & \text { R. W. Glass } \\ 20 . & \text { R. F. Holdaway } \\ 21 . & \text { K. G. Kahl } \\ 22 . & \text { C. D. Liles } \\ 23-32 . & \text { S. D. Moses } \\ 33 . & \text { W. O. Nobles } \\ 34 . & \text { R. D. Poor }\end{aligned}$

1-5. J, C. Anderson

$6 . \quad$ H. C. Beeson

8. R. W. Bieniek

9.

10.

12.

$13-17$.

18.

19.

20.

21.

22 .

33.

34.
35. J, C. Salyers

36. W. C. Stoddart

37. E. Stumpfl

38. A. J. Szady, Jr.

39. P. A. Tabor

40. D. A. Tolletison

41. M. S. Walker

42. J. C. Walls

43. D. E, Welch

44. W, R, Williams

45-46. Central Research Library

47. Y-12 Technical Reference Section

48. Y-12 Plant Records

49. Laboratory Records

50. Laboratory Records - Record Copy

51. ORNL Patent Section

\section{EXTERNAL DISTRIBUTION}

52. Assistant manager for Energy Research and Development, DOE-OR, P.O. Box 2001, Oak Ridge, TN 37831.8600$)$

53. Frank Punch, U.S. Dept, of Energy, EH-33.3 GTN, Washington, D.C. 20585

54. Roger W. Carlson, Lawrence Livermore National Laboratory, P. O. Box 808, Mail Code L-197, Livermore, CA 94551

55. Larry E. Fisher, Lawrence Livermore National Laboratory, P. O. Box 808, Mall Code L-197, Livermore, CA 94551

56. James $H$. VanSant, Lawrence Livermore National Laboratory, P. O. Box 808, Mail Code L-197, Livermore, CA 94551

57-68. Office of Scientific and Technical Information, P. O. Box 62, Oak Ridge, TN 37831 


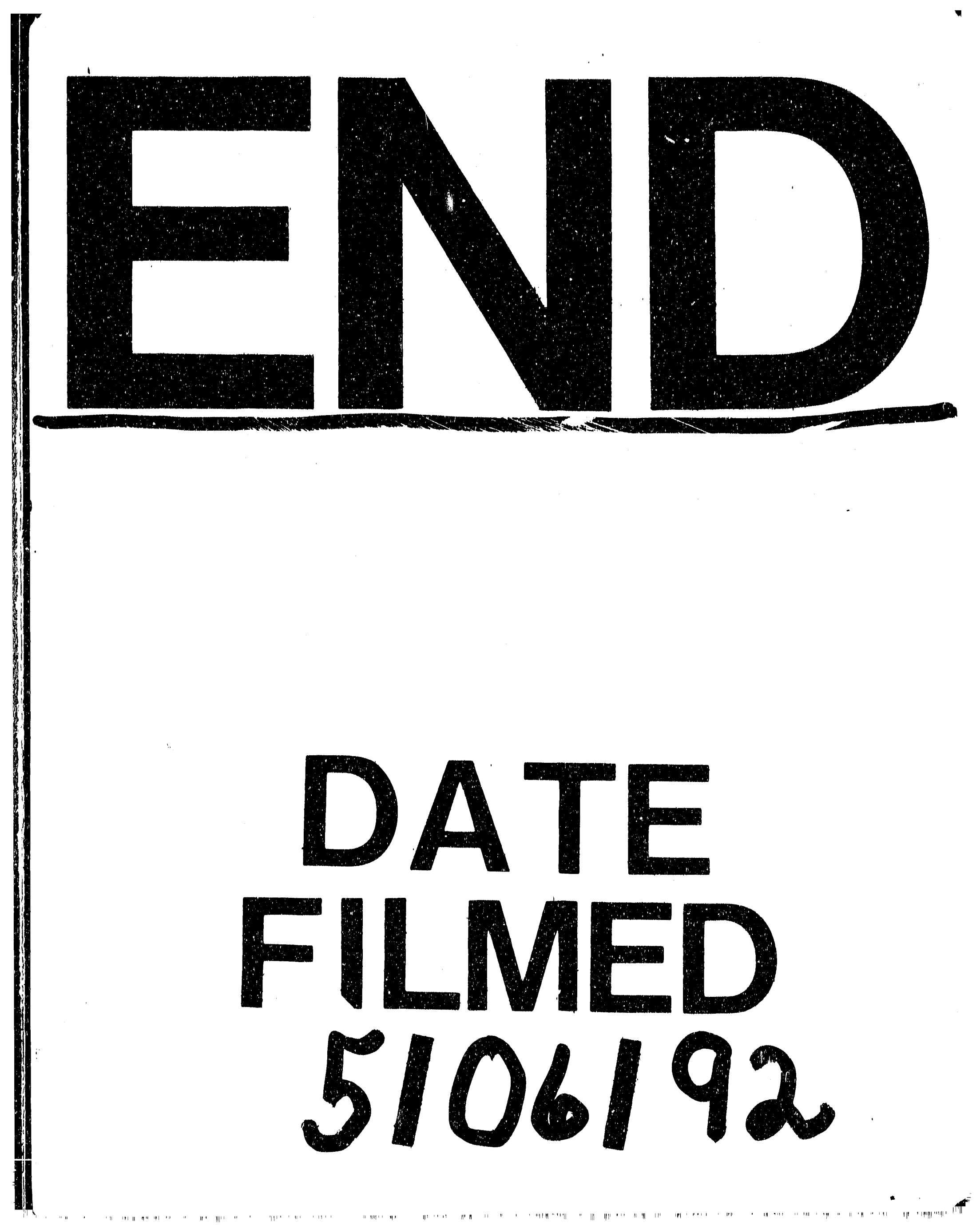


